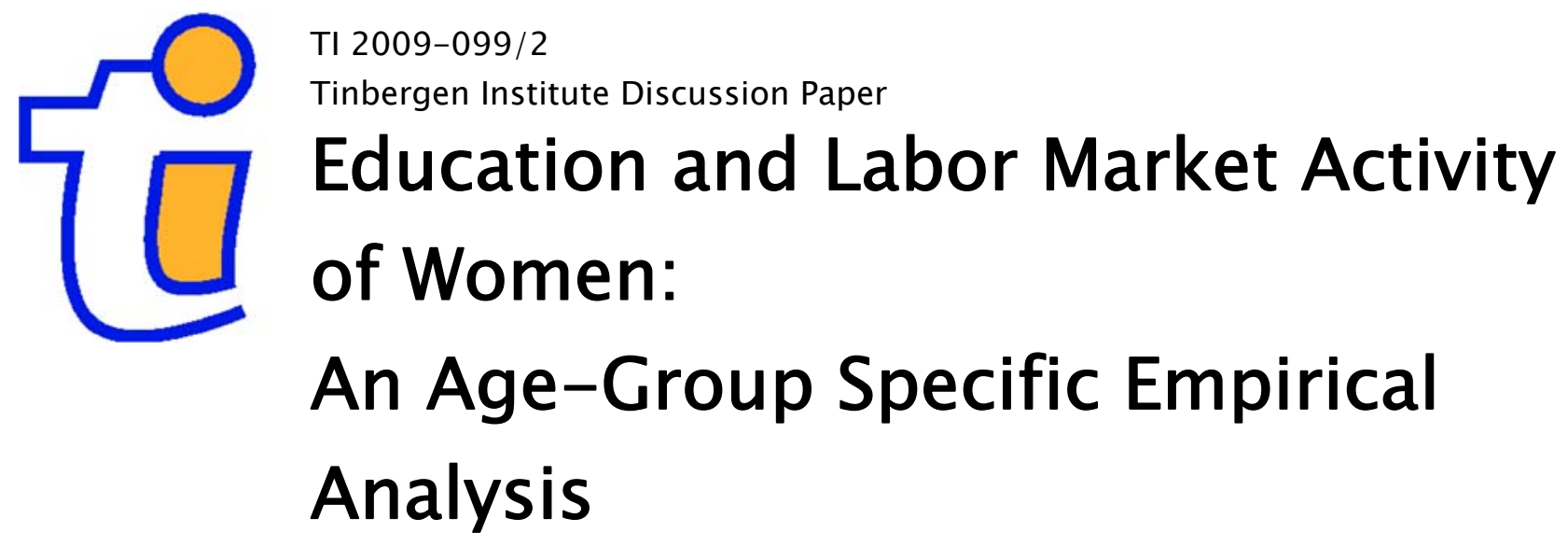

Claudia Münch

Sweder van Wijnbergen*

University of Amsterdam

* Tinbergen Institute 


\section{Tinbergen Institute}

The Tinbergen Institute is the institute for economic research of the Erasmus Universiteit Rotterdam, Universiteit van Amsterdam, and Vrije Universiteit Amsterdam.

Tinbergen Institute Amsterdam

Roetersstraat 31

1018 WB Amsterdam

The Netherlands

Tel.: +31(0)205513500

Fax: $+31(0) 205513555$

Tinbergen Institute Rotterdam

Burg. Oudlaan 50

3062 PA Rotterdam

The Netherlands

Tel.: + $31(0) 104088900$

Fax: $+31(0) 104089031$

Most TI discussion papers can be downloaded at http://www.tinbergen.nl. 


\title{
Education and labor market activity of women: an age-group specific empirical analysis
}

\author{
Claudia Münch ${ }^{1}$
}

and

\author{
Sweder van Wijnbergen \\ University of Amsterdam \\ and the Tinbergen Institute
}

Abstract:

We analyze the determinants of female labor market participation for different age-groups in the European Union. We show that female participation is positively affected by tertiary education at any age. But upper secondary education increases participation only up to an age of 40 while after that it has no effect or even a negative impact The results are tested for robustness and controlled for endogeneity. The results show that increasing educational attainment levels in the female population will contribute significantly to higher aggregate participation rates. However, in simulations up to 2050 such benefits are partially offset by a negative aging effect.

\footnotetext{
${ }^{1}$ This paper is based on the first author's Master Thesis presented for the Master of Science in Economics, University of Amsterdam, Faculty of Economics and Business.
} 


\section{Introduction}

Especially since the Lisbon Agenda in 2000, policy interest has focused on increasing female labor market participation in order to promote employment in the European Union (European Council, 2000). Facing the accelerating aging of the population in Europe, higher employment rates could alleviate the pressure on the fiscal sustainability of PAYG pension systems (European Commission, 2002). Aggregate female labor market participation did rise over the last decade, but participation rates still vary considerably accross countries. Focusing on women aged between 25 and $64^{2}$, their participation rates range from about 80 percent in Scandinavian countries and Latvia to about 60 percent in Greece and Hungary, 56 percent in Italy and only 38 percent in Malta. Moreover, participation rates differ not only among countries but also within countries by age-groups (see Figure 1). Since aggregate participation rates follow from age-group specific participation rates (Balleer et al., 2009), a better understanding of why participation rates differ between age groups may well be essential for any effort to increase aggregate participation.

All labor markets of the EU countries share one distinct feature: their female labor participation rates vary widely by the educational attainment level. It is striking that, with only few exceptions, female labor force participation increases with the level of education for all age-groups (see Figure 2). The same relation between education and participation can therefore also be observed at the aggregate level in all countries. In 2008, for instance, 53.4 percent of Dutch 25-64 old women with primary or lower secondary education degrees participated in the labor market, whereas, of the same age-group, 77.6 percent of women who finished upper secondary education and 87.2 percent of women with tertiary educational attainment participated in the labor market. A logical question is then whether promoting access to higher education would lead to higher participation rates of all age-groups in the long run.

\footnotetext{
${ }^{2}$ The aggregate working-age population is normally defined over the age-group 15-64 (Eurostat, 2009). This definition, however, is not appropriate for the purpose of this study where the focus is on the actual (potential) workforce with fully formed education. Therefore we focus on the age-groups between 25 and 64 years.
} 
Figure 1: Female labor force participation by country and age-group in 2008

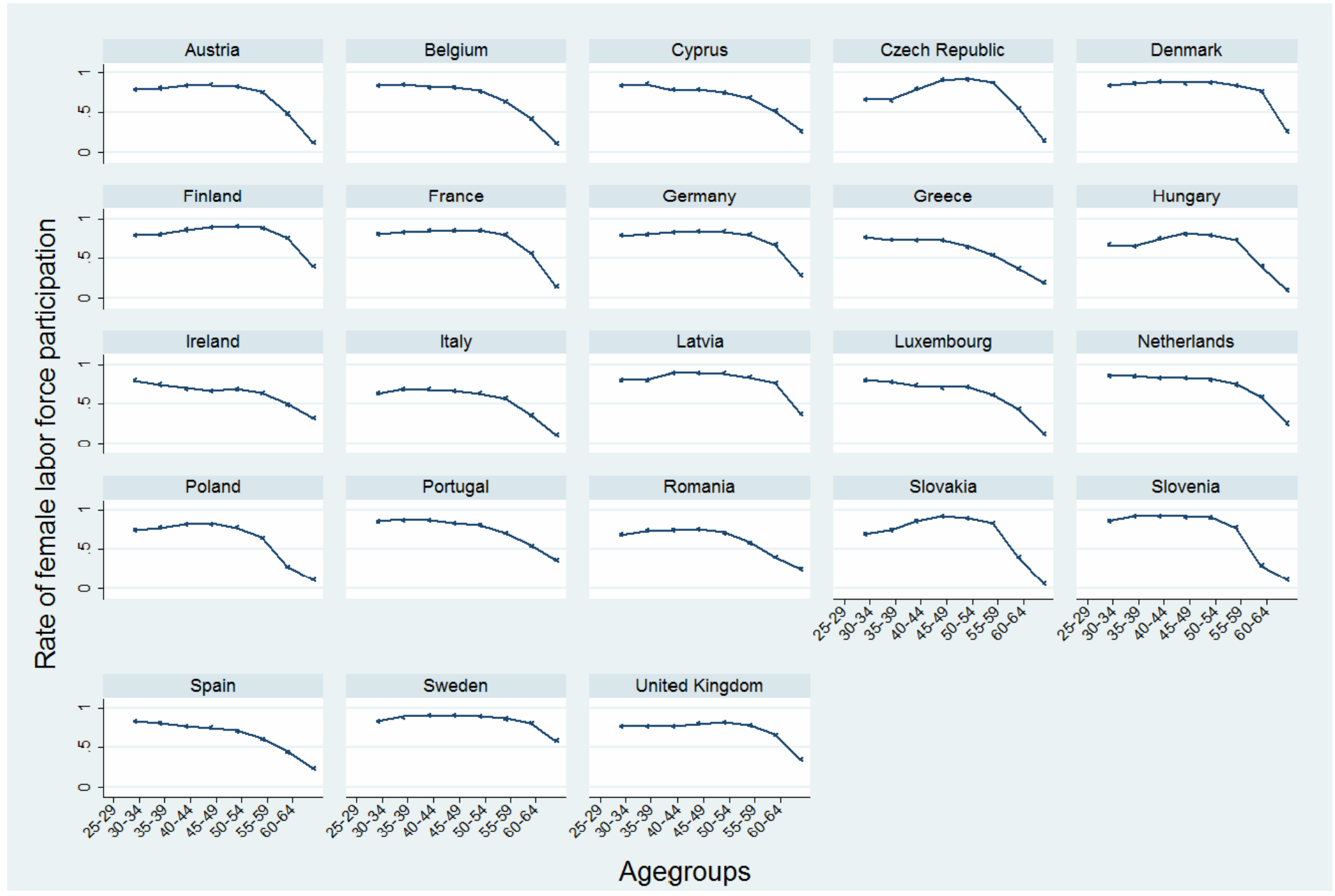

Source: Eurostat-Labor Force Survey (2009a) 
Figure 2: Female labor force participation by country, age and educational attainment level in 2008

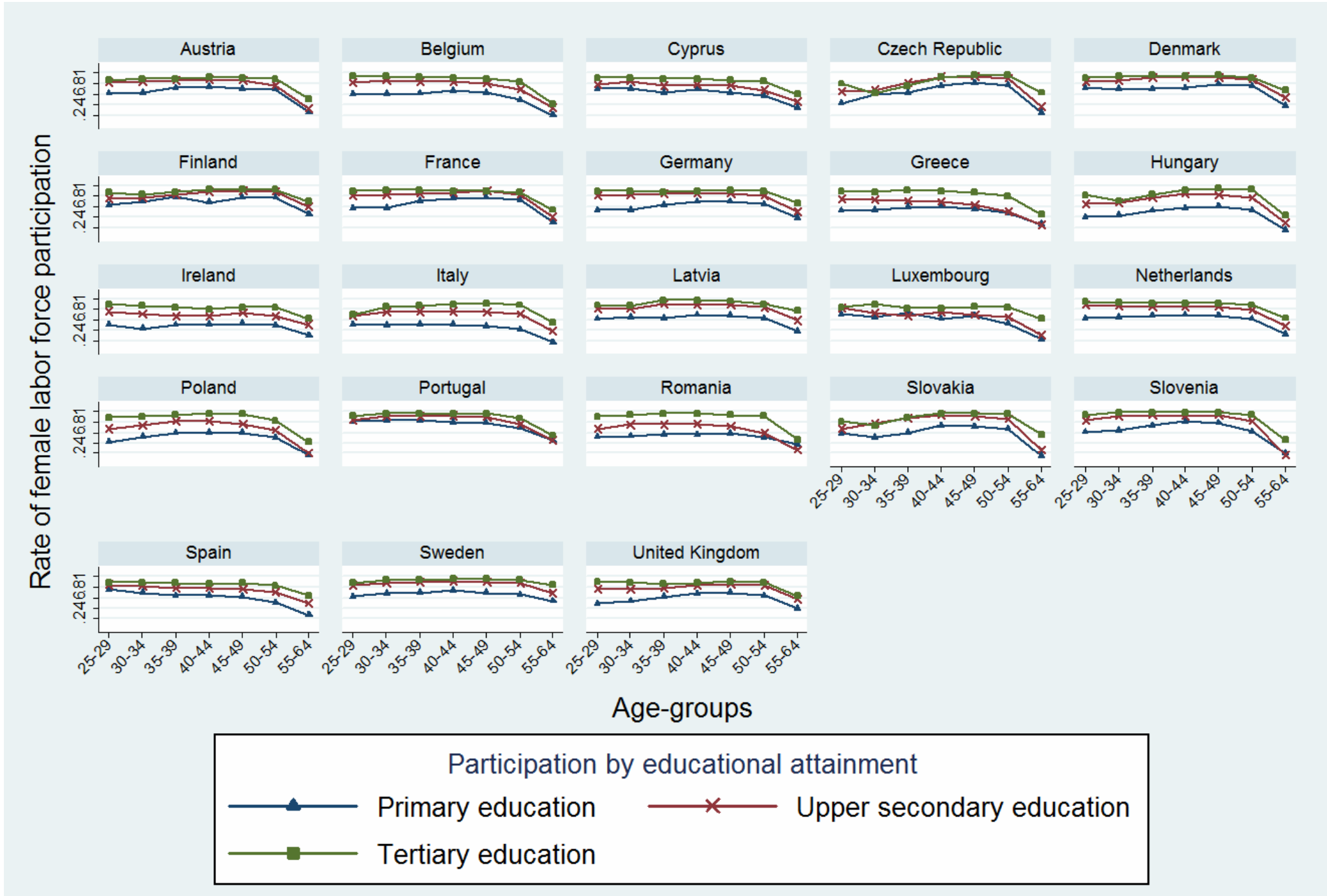

Source: Eurostat-Labor Force Survey (2009a) 
In order to assess the impact of education on female labor market participation of different age-groups, the empirical analysis estimates a separate female labor market participation equation for eight age-groups of five years each between 25 and 64 years. The analysis is based on annual macro data for a panel of $23 \mathrm{EU}$ countries over the period 1995 to 2008 . For educational attainment rates, the main explanatory variable, we use annual data for each agegroup. Such detailed data allow for a thorough analysis of the impact of education on agegroup specific participation behavior of women. In addition to educational attainment levels, the empirical analysis includes a range of aggregate control variables that consider the economic conditions, demographic indicators, gender discrimination and the institutional framework.

The results show that the educational attainment level matters for female labor force participation rates, for all age-groups. Female labor force participation is significantly and positively affected by higher (tertiary) education. Upper secondary education, by contrast, increases the propensity to work only up to an age of 40 while after that age it does not seem to play a role in participation decisions; it even has a strong negative impact on participation in case of women aged 55-59. The results are tested for robustness and controlled for endogeneity. For the European countries that are faced with an accelerating aging population these results are of great importance. The results indicate that the educational attainment level has a long-term impact on participation. A simulated future scenario for 2050 suggests that increasing the educational achievement of women could contribute to increase aggregate participation rates. However, the increases in participation rates are partially offset by a strong negative aging effect that will occur whether there is a rise in educational achievement or not.

In what follows, section 2 discusses three recent cross country studies of female labor market participation behavior, section 3 describes the data and the empirical model before section 4 explains the empirical strategy and presents the estimation results. Section 5 simulates a possible future scenario. Section 6 concludes.

\section{Setting the scene: the need for higher female labor force participation and recent cross country studies}

An aging population will be one of the major economic and social challenges in European countries in the upcoming decades. Rising public and private spending for social security systems such as pension, health and elderly care will put pressure on the fiscal sustainability 
of Europeans welfare states. At the same time, economic growth is at risk due to the gradually shrinking working age population. ${ }^{3}$

Increasing labor market participation rates could attenuate the detrimental impacts of the demographic change, mostly by broadening the contribution base of PAYG pension suystems (European Commission, 2002; Euwals et al., 2007). In most countries the participation rate of women is still low compared to male participation rates and therefore constitutes an important potential source of additional labor supply.

Increasing female labor force participation through policies that strengthen the access to education would not only affect the quantity but also the quality ${ }^{4}$ of the labor force. Obviously, higher education levels will filter through slowly into older age-groups. However, even if the impact is slow to materialize, it can be an important in the long-term instrument to increase labor force participation whilst obtaining a better skilled workforce at the same time. In this way it might promote long-term economic growth even in per capita terms (Gros and Roth, 2008).

There is a growing empirical literature dealing with female labor market participation behavior. Although the use of microeconomic data is predominant in the literature ${ }^{5}$, there are some recent cross-country studies using macroeconomic data.

Jaumotte (2003) provides a comprehensive study on the determinants of the aggregate female labor force participation in 17 OECD countries over the period 1985-1999. Her findings suggest that higher female education, the conditions of the labor market and cultural attitudes play a major role in determining female labor market participation. Besides, policies pursuing a more neutral family taxation, the availability of flexible time arrangements, family support in the form of childcare subsidies and paid parental leave all encourage female labor force participation. She does not however distinguish between different age groups.

For the present paper, empirical cross country studies that do not only analyze gender specific participation behavior but also distinguish between different age-groups such as Bloom et al. (2009) and Genre et al. (2005) are of particular interest. Bloom et al. (2009) analyze the

\footnotetext{
${ }^{3}$ For recent analyses of the economic impacts of population aging see e.g. Balassone et al. (2009) for a study of the Euro area and Van Ewijk et al. (2006) for a study focusing on the Netherlands.

${ }^{4}$ Increased enrolment rates may have to be complemented by higher-quality education.

${ }^{5}$ For example Euwals et al. (2007) study female labor force participation in the Netherlands using micro data from the Dutch Labor Force Survey. Their results indicate that increasing education, diminishing negative effects of children and unobserved cohort effects are important determinants of participation behavior of Dutch women.
} 
causal effect of fertility on female labor force participation drawing on a 5-yearly panel for 97 countries that covers the period 1960 to 2000. For five age-groups between 20 and 44 (in increments of five years) a female labor force equation is estimated. OLS estimations indicate a significant and negative impact of fertility on female labor force participation at any age. Female education enters positively and statistically significant in each age-group regression. To take account of the potential endogeneity bias of fertility decisions, abortion legislation is used as an instrument for the total fertility rate. Using an IV approach, the coefficient of fertility stays negative and significant, but female education loses its significance. However, Bloom et al. find that female education still appears to have a strong negative impact in the first stage regression implying an indirect effect of education on female labor force participation through fertility.

Genre et al. (2005), using an annual panel of 12 EU15 countries over the period 1980-2000, estimate a female participation regression for three age-groups: young, prime-age and elderly women. Their results show that strict labor market institutions have a negative impact on female labor market activity at any age, although less so at younger ages. Education decisions have, as can be expected, a negative impact on younger age-groups due to enrollment in education. Young women's participation rates are positively affected by the availability of part-time work and negatively by the unemployment rate. In the regression for prime-age women, education is used as proxy for wages, but without conclusive results. Their participation rates are negatively affected by the fertility rate and, as in the case of younger women, the unemployment rate. Maternity leave policies (up to 10 months) and the availability of part-time work stimulate prime-aged women's participation decisions. In the regression for elderly women, education is not included as an explanatory variable. Their participation behavior is largely influenced by their previous behavior. Women that did not participate during their prime-age are less likely to participate when they grow older.

The reviewed studies use education data from the Barro and Lee (2001) dataset - a widely used dataset in macroeconomic studies. The dataset provides comparable cross country education indicators for the years between 1960 and 2000. However, data are only available in intervals of five years, values for 2000 rely on projections and there is a differentiation for gender but not between age-groups.

The use of recent age-group specific annual education data within a broad cross country analysis of female labor market participation is the innovative feature of the present empirical 
study, allowing for more reliable estimates of the impact of education on female labor force participation behavior.

\section{Empirical analysis}

In European countries, female labor force participation rates vary by age (cf. Figure 1) which indicates differences in the underlying labor market behavior of women in different agegroups. The empirical work aims at dissecting the determinants of age-group specific participation rates of women within a cross-country analysis. For this purpose it estimates a separate participation equation for each age-group. The following section first discusses the data used for the empirical analysis before it turns to the empirical model.

\subsection{Data}

The data set used for the empirical work is an annual panel ${ }^{6}$ covering the period $1995-2008$ for 23 European countries. The countries included are the EU27 countries except for Bulgaria, Estonia, Lithuania and Malta because data of these countries are either missing or extremely unreliable. ${ }^{7}$ The data used are taken from a number of publicly available data sources in order to construct a comprehensive data set. Table A1 in the Annex gives an overview of all variables, their definitions and sources.

The dependent variable in the analysis is the age-group specific female labor force participation rate. Participation data are taken from Eurostat-Labor Force Survey (2009a). The Eurostat-Labor Force Survey provides age-group specific comparable cross national data for female activity rates. The female participation rate is defined as the number of economically active women in the labor force in a given age-group divided by the female population of that age-group. 'Economically active' is defined as either working or actively looking for work. ${ }^{8}$

The focus of the empirical analysis is on the impact of educational attainment of women in different age-groups on the participation rates in these age-groups. Educational attainment data are also taken from Eurostat-Labor Force Survey (2009a). Information is given in numbers of women (in thousands). In order to calculate the rate, age-group specific educational attainment data are divided by the female population of the respective age-group. Population data are taken from Eurostat (2009) and are supplemented with data from ILOLABORSTA (2009) for the year 2008. Education levels are classified according to

\footnotetext{
${ }^{6}$ The panel is unbalanced due to data limitations.

${ }^{7}$ Cf. Eurostat-Labor Force Survey (2009a).

${ }^{8}$ There is no information on whether the work is a full-time or a part-time occupation.
} 
International Standard classification 1997 - ISCED 97 - from UNESCO (1997). The ISCED 97 provides a cross-national classification framework for harmonizing educational programs and qualifications. ${ }^{9}$ The data provided by the Eurostat-Labor Force Survey distinguish between primary and lower secondary education, upper secondary education and tertiary education.

Primary education (including pre-primary education) and lower secondary education provide basic mathematical, writing and reading skills. Lower secondary education usually ends after some nine years after the beginning of primary education. Primary and lower secondary education is compulsory in most countries.

Upper secondary education follows lower secondary education and consists of several tracks and programs (general, technical and vocational programs). Pupils starting upper secondary education are normally about 15 to 16 years old. ${ }^{10}$

Tertiary education requires the successful completion of upper secondary education and consists of theoretically based, occupation- oriented and advanced research programs such as $\mathrm{PhD}$ or doctorate studies. The definition of primary and lower secondary education refers to ISCED 97 levels 0-2, upper secondary education to levels 3 and 4 and tertiary education to levels 5 and 6 .

It should be mentioned that, in the dataset, the levels primary/lower secondary, upper secondary and tertiary education do not sum up to 1 but close to. This can have several reasons, namely coverage errors, measurement errors, processing errors, non-responses in the surveys, changes in the survey characteristics and estimates of missing data in the surveys. ${ }^{11}$ Errors may also occur because of inconsistencies between the two datasets used (education dataset and population dataset). As the differences in most cases are minor, we still consider the shares of primary/lower upper secondary, upper secondary and tertiary educational attainment rate as dependent on each other. A higher percentage for one education level as the highest one attained implies a decrease for at least one of the two remaining education levels. The empirical model thus includes only two education levels - namely upper secondary and tertiary education.

\footnotetext{
${ }^{9}$ ISCED 97 is the modified version of the first version ISCED 76 (UNESCO 1997).

${ }^{10}$ The category upper secondary also includes post secondary non-tertiary education. The classification refers to programs that serve to broaden the knowledge of the pupils after completing upper secondary education but do not provide an essentially higher content. For a more detailed description of the classification standards see UNESCO (1997).

${ }^{11}$ See Eurostat-Labor Force Survey (2009b) for a discussion of problems concerning the metadata used for the Labor Force Survey.
} 
The empirical analysis further includes explanatory variables representing economic, demographic, social policy and gender discrimination indicators. These are the total female unemployment rate, total female part-time employment, logarithm of GDP per capita and its square, crude marriage and divorce rate, total fertility rate, duration of paid maternal leave, public expenditure for pensions (in percent of GDP), public expenditure for formal child day care (in percent of GDP), proportion of seats in national parliaments held by women and unadjusted gender paygap.

Female labor force participation data and education data cover eight age-groups: 25-29, 30$34,35-39,40-44,45-49,50-54,55-59,60-64 .^{12}$ For the control variables, the analysis uses data that are aggregated over age-groups. Table A2 in the Annex gives summary statistics for participation and education data.

The dataset contains 322 observations for each age-group specific participation rate. It shows that mean participation rates are declining with age. While the (mean) participation rate of women up to the age-group 45-49 is about 75 percent, the (mean) participation rate of the agegroup 60-64 is only 19 percent.

The data also show a large variation in participation rates across countries for each agegroup. For instance, for the age-group 35-39, participation rates range from 52 percent in Luxembourg (1995) to 97 percent in Slovenia (1998). For the age-group 60-64, participation rates vary between 2.7 percent of women aged 60-64 in Slovakia (1999) ${ }^{13}$ to 59 percent in Sweden (2007). Scandinavian countries show also the highest participation rates for the agegroups 50-54 and 55-59 (Finland in 2008 and Sweden in 2008, respectively).

A comparison of the age-group specific female participation rates of 1995 with those in 2008 (see Figure 3) shows a general increase in participation rates although the integration of women is not evenly distributed over age-groups and differs in size as well as between countries. Romania is a clear exception from this pattern with decreasing participation rates in all age-groups.

\footnotetext{
${ }^{12}$ The choice of the age-group is explained in footnote 1.

${ }^{13}$ Note that the pension eligibility age in Slovakia is lower than 65. Up to a pension reform in 2004, the pensionable age was 53-57, since then it is gradually increasing to 62 (OECD, 2005; eironline, 2004). The participation rates of the age-groups between 25 and 55 are relatively high in Slovakia.
} 
Figure 3: Female labor force participation by age and country in 1995 and 2008

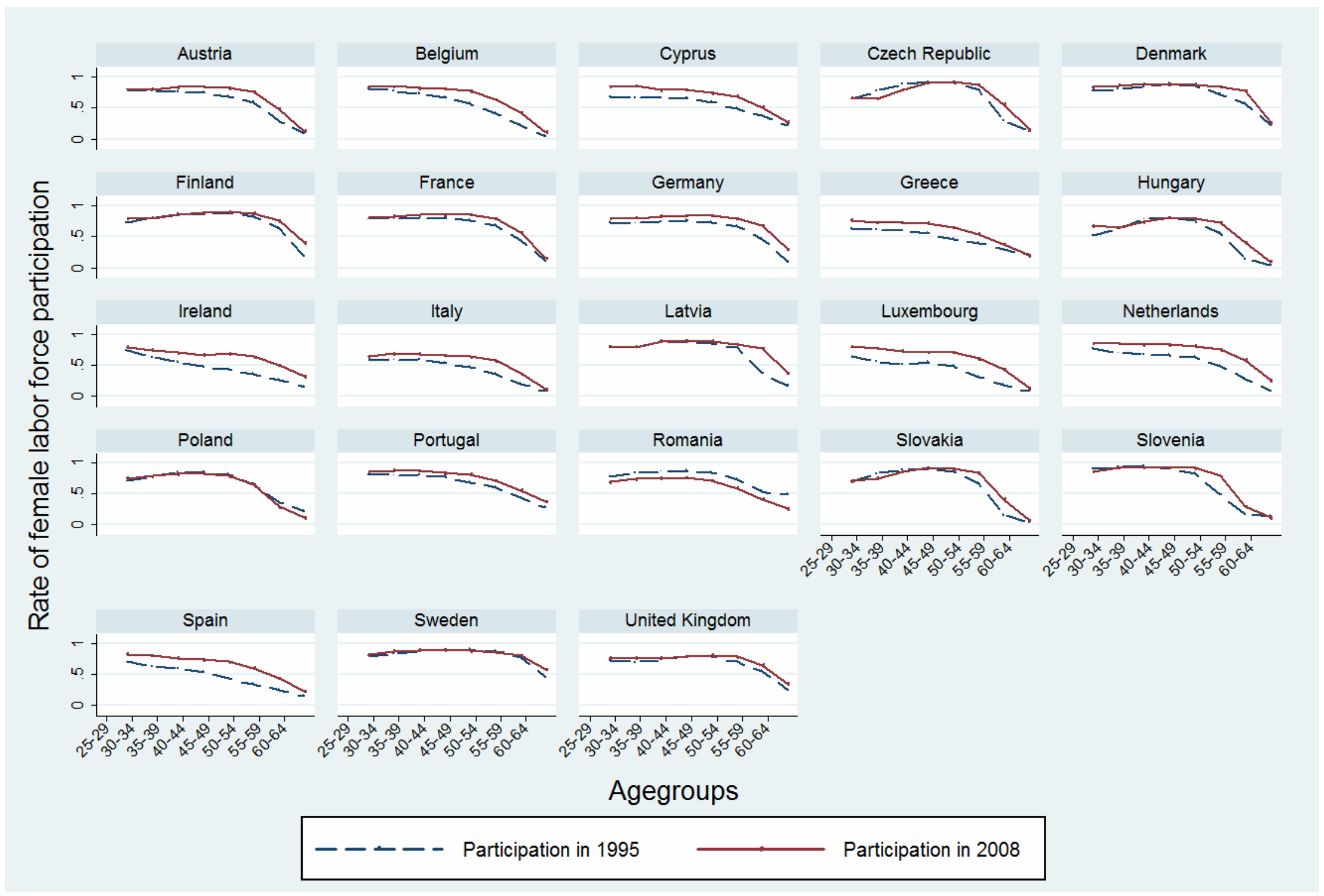


For educational attainment rates, the dataset contains 301 observations for the age-groups between 25 and 59. For the age-group 60-64, data for United Kingdom had to be left out because of inconsistencies in the data set, leaving 287 observations. Education data show large variations across countries for each age-group and education level.

In order to give an idea of the change which occurred over time, figure 4 shows the difference in the highest educational attainment of women aged 25-29 between the year 1995 and the year 2008, to the extent that data for 1995 were available. Otherwise, the earliest available year was taken. With only very few exceptions, the countries show a striking pattern: the difference of tertiary educational attainment level is positive for all countries (Luxembourg shows the highest increase with 30 percentage points), while the differences of upper secondary and primary/lower secondary education tend to be negative.

Obviously, unlike participation, educational attainment is not reversible when growing older which means that today's young age-groups will have a higher educational attainment when they are old as compared to today's older age-groups. Yet, figure 4 should not hide the fact that European countries still feature considerable differences in their educational attainment rates. In Portugal 39.3 percent of the female population aged 25-29 had only primary/lower secondary education in 2008, 25.3 percent achieved at most upper secondary education and 32.5 percent achieved tertiary education. By contrast, in Sweden only 8.6 percent of women aged 25-29 achieved at most primary/lower secondary education, 47.2 percent of women achieved at most upper secondary education and 45.9 percent achieved tertiary education. Table 1 shows the distribution for the educational attainment rates in 2008. 
Figure 4: Difference of highest education level attained of female population (age-group 25-29) between 1995 and 2008

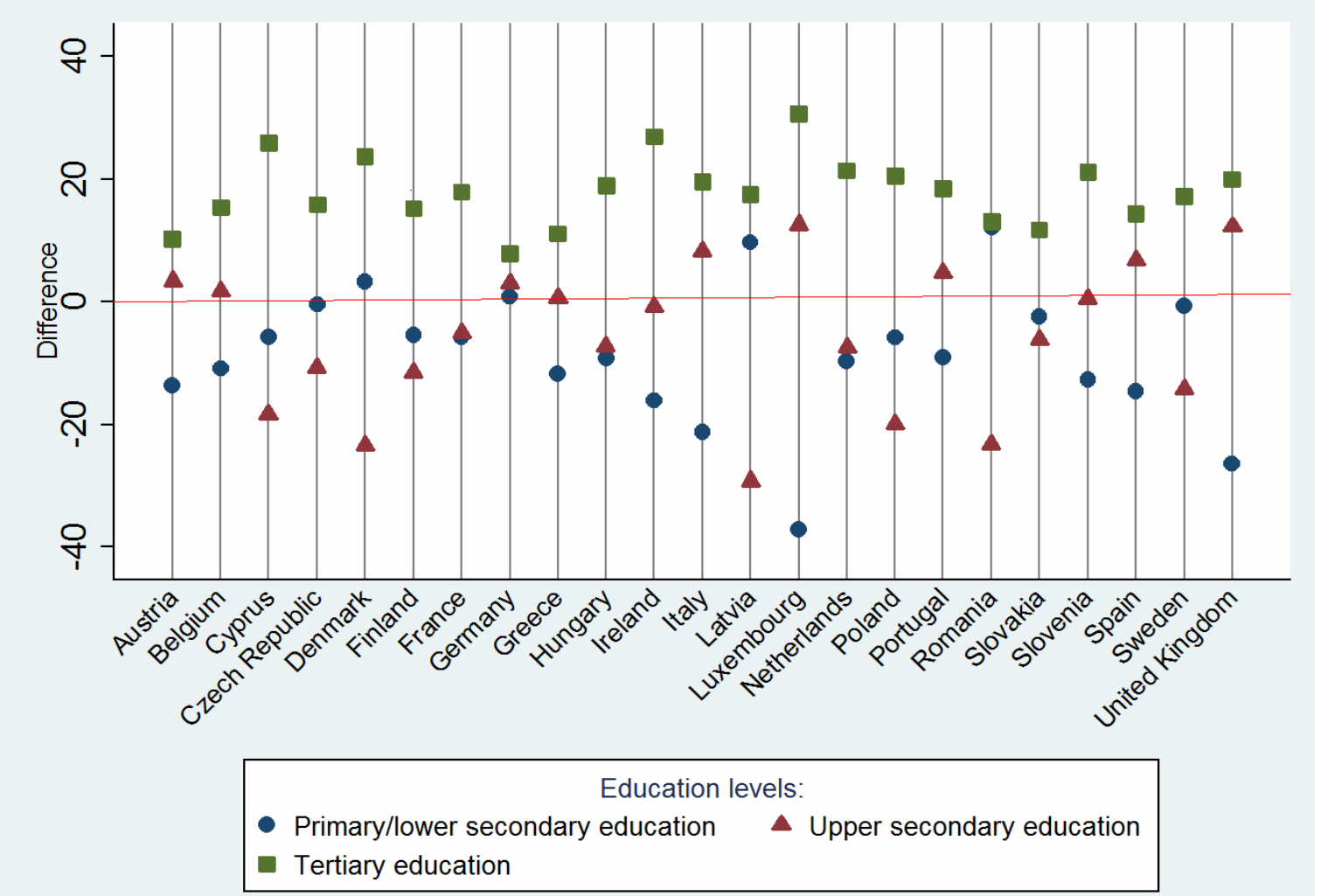

For the Netherlands and Slovenia the base year is 1996, for Hungary, Poland and Romania 1997, for the Czech Republic, Latvia and Slovakia 1998 and for Cyprus 1999.

Table 1: Educational attainment rates of women aged 25-29 in 2008

\begin{tabular}{|c|c|c|c|}
\hline Country & Primary/lower secondary & y Upper secondary & Tertiary \\
\hline Austria & 0.127 & 0.717 & 0.186 \\
\hline Belgium & 0.153 & 0.399 & 0.517 \\
\hline Cyprus & 0.111 & 0.323 & 0.562 \\
\hline Czech Republic & 0.058 & 0.721 & 0.249 \\
\hline Denmark & 0.132 & 0.401 & 0.459 \\
\hline Finland & 0.081 & 0.511 & 0.392 \\
\hline France & 0.164 & 0.395 & 0.459 \\
\hline Germany & 0.146 & 0.656 & 0.235 \\
\hline Greece & 0.167 & 0.452 & 0.341 \\
\hline Hungary & 0.127 & 0.559 & 0.303 \\
\hline Ireland & 0.113 & 0.397 & 0.573 \\
\hline Italy & 0.257 & 0.534 & 0.271 \\
\hline Latvia & 0.150 & 0.457 & 0.380 \\
\hline Luxembourg & 0.193 & 0.427 & 0.460 \\
\hline Netherlands & 0.149 & 0.428 & 0.438 \\
\hline Poland & 0.047 & 0.500 & 0.397 \\
\hline Portugal & 0.393 & 0.253 & 0.325 \\
\hline Romania & 0.239 & 0.542 & 0.245 \\
\hline Slovakia & 0.050 & 0.712 & 0.248 \\
\hline Slovenia & 0.039 & 0.584 & 0.391 \\
\hline Spain & 0.320 & 0.290 & 0.451 \\
\hline Sweden & 0.086 & 0.472 & 0.459 \\
\hline United Kingdom & 0.187 & 0.448 & 0.415 \\
\hline
\end{tabular}




\subsection{The empirical model}

At the individual level, the decision of a woman to participate in the labor market is a discrete choice (Elhorst and Zeilstra, 2007). A woman decides to participate if the benefits from working exceed the loss of benefits from home production and the possible (value of the) loss of leisure. Otherwise, she stays outside the labor market (or leaves the market). Benefits in the labor market are determined by the remuneration from work in form of earnings while benefits from non-participation depend on non-labor income from home production and the utility of leisure. Both forms of benefits are equally shaped by preferences. The possibilities and earning power of women in the labor market depend on their skills and the availability of suitable jobs. The restrictions women are faced with are given by individual time and budget constraints, restrictions imposed by the labor market and social attitudes/norms towards women (Vlasblom and Schippers, 2004). ${ }^{14}$

At the country level, the participation rate is the proportion of women (of a certain age-group) in the female working-age population (of that age-group) that decided to participate in the labor market. It is therefore bounded between 0 and 1 (Elhorst and Zeistra, 2007).

A bounded dependent variable needs to be treated with caution when the explanatory variables and the error terms are unrestricted because if one assumes a simple linear relation the predictions may take values outside the finite interval allowed. The empirical analysis takes account of the boundedness of the participation rate by estimating the female participation rate using a logistic regression model. ${ }^{15}$ Specifying the proportion of women that participate as a logistic regression model (1) ensures that the predicted values of the dependent variable lie inside the interval 0-1 even if the explanatory variables take unrestricted values and thus allows for more reasonable estimates. ${ }^{16}$

$$
\text { (1) } F L P=\frac{1}{1+e^{-(\alpha+\beta X)}} \equiv \frac{e^{(\alpha+\beta * X)}}{1+e^{(\alpha+\beta X)}}
$$

where FLP is the female labor market participation rate and $X$ is a vector containing the explanatory variables. An alternative and more convenient form of the logistic regression model is in terms of the odds of the dependent variable.

\footnotetext{
${ }^{14}$ For a comprehensive discussion of theoretical models of female labor supply see Heckman and Killingsworth (1986).

${ }^{15}$ The estimation approach is based on Genre et al. (2005).

${ }^{16}$ The explanation of the logistic regression model is based on Aldrich and Nelson (1984) and Gujarati (2003).
} 
If FLP is the proportion of women that participate in the labor market, $(1-F L P)$ is the proportion of women that stay outside the market (2).

(2) $(1-F L P \quad)=\frac{1}{1+e^{(\alpha+\beta * X)}} \equiv \frac{e^{-(\alpha+\beta * X)}}{1+e^{-(\alpha+\beta * X)}}$

Dividing (1) by (2) yields the odds of female participation (3).

(3) $\frac{F L P}{1-F L P}=\frac{e^{(\alpha+\beta * X)}}{1+e^{(\alpha+\beta X)}} / \frac{e^{-(\alpha+\beta * X)}}{1+e^{-(\alpha+\beta * X)}}=e^{(\alpha+\beta * X)}$

Taking the logs from (3) gives:

(4) $\log \left(\frac{F L P}{1-F L P}\right)=\alpha+\beta * X$

Equation (4) shows that the log odds of the participation rate are linearly related to the explanatory variables and can take values on the entire real axis. The female labor force participation, however, is nonlinearly related to the explanatory variables and can only take values between 0 and 1.

The empirical analysis estimates the following female labor force equation for each age-group $\mathrm{i}$ $=25-29,30-34,35-39,40-44,45-49,50-54,55-59,60-64$ :

$\log \left(\frac{F L P_{i j t}}{1-F L P_{i j t}}\right)=\alpha_{i}+\beta_{i} U S_{i j t}+\gamma_{i}$ Ter $_{i j t}+\phi_{i} \operatorname{Dem}_{j t}+\kappa_{i} E_{C o}+\delta_{i} G_{j t}+\sigma_{i} P_{j t}+\delta_{i j}+\varepsilon_{i j t}$

where the dependent variable is the logistic transformation of the female labor force participation rate (FPR) and $j$ and $t$ are the indices for country and time, respectively.

For each age-group the empirical model contains a range of general explanatory variables to test if the marginal reactions to changes of these variables vary between age-groups. The main explanatory variables are upper secondary (US) and tertiary (Ter) educational attainment rate of women in the respective age-group $i$. The empirical analysis controls for aggregate demographic (Dem), economic (Eco) and gender discrimination (Gen) indicators. The analysis further controls for social policies $(\mathrm{Pol})$ that address only specific age-groups. $\delta_{i j}$ is an unobserved country effect and $\varepsilon_{i j t}$ is the error term. 


\section{Educational attainment:}

Higher education is supposed to increase potential earnings by increasing human capital and productivity (Vlasblom and Schippers, 2003). ${ }^{17}$ In addition to potential earnings, education may have an influence on female labor market behavior via tastes. The attainment of higher education might change the traditional idea of individual fulfillment of a women by creating the desire to realize an own professional career. Work is not only seen as an obligation but as an aspect of life satisfaction and social life. The decision to work thus implies a decision of personal identity (Goldin, 2006). The pursuit and the duration of individual fulfillment through a career on the labor market are expected to increase with the level of education.

\section{Demographic indicators:}

As demographic indicators the empirical analysis contains the marital status represented by the crude marriage and divorce rate and the total fertility rate. Increasing divorce rates induce a woman to stay economically independent when married in order to hedge against the divorce risk and are thus expected to have a positive effect on female labor force participation. Marriage rates are expected to operate in the opposite direction (Bremmer and Kesselring, 2004).

Female labor force participation is often linked to declining fertility rates. Fewer children reduce the value of time spent at home. However, the picture in the European Union is diffuse. Some countries show low fertility rates and low participation rates as can be seen in Italy and Greece while others again show high fertility rates and high participation rates as mainly observed in the Scandinavian countries (Jaumotte, 2003; Del Boca et al., 2005).

\section{Economic situation and availability of jobs:}

The labor market situation impacts the availability of jobs (Genre et al., 2005). An unfavorable labor market situation might induce women to withdraw from the labor market in the belief that they would not find a suitable job. The empirical analysis controls for the female unemployment rate expecting a negative, discouraging, effect on female labor participation decision (Euwals et al., 2007).

Furthermore, the flexibility of working time arrangements could be a decisive factor of female labor market participation decisions. The share of female part-time work in total female employment is used as a proxy for the flexibility of working time (Jaumotte, 2003; Genre et al., 2005).

\footnotetext{
${ }^{17}$ For recent empirical studies of the impact of education on earnings see e.g. (Brunello and Comi, 2004; Gørgens, 2002).
} 
Economic literature finds that female labor force participation first declines with increasing income per capita due to the shift away from agriculture and a transition towards a male breadwinner family. After a certain threshold, participation starts to increase again due to an expanding service sector with more working opportunities for women, better educated women and changing ideologies (e.g. Goldin, 1994). The logarithm of GDP per capita and its square are included to control for a U-shape relationship of female labor force participation and economic growth (Luci, 2009).

\section{Discrimination in the labor market:}

Discrimination against women in the labor market is expected to negatively influence female labor market behavior by decreasing their chances to find a suitable job and their potential earnings. The empirical model tries to capture gender discrimination by including the proportion of seats in national parliaments held by women (as used in Genre et al., 2005) and the (unadjusted) gender paygap in the regression. The former is expected to positively impact female participation while the latter should have a negative impact.

\section{Social Policies:}

Social policies that aim at facilitating a woman's re-entrance in the labor market and allow reconciling family with a professional career are expected to have a positive effect on prime-age women's participation decisions (Genre et al., 2005; Jaumotte, 2003). For controlling family friendly policies, the empirical model includes paid maternal (parental) leave (and its square to control for a potentially changing behavior depending on the length of maternal leave) as well as public expenditure for childcare arrangements.

Furthermore, the national family taxation system is expected to affect female labor force decisions. Jaumotte (2003) finds that a neutral taxation of the second earner relative to single individuals enhances female labor force participation. However, due to data limitations, the empirical model misses a variable describing the tax system.

Generous pension systems are expected to induce a strong income effect and thus negatively influence participation decision of elderly women (Boeri, 2005; Genre et al., 2005). The empirical model includes social protection expenditure for old age pensions as an admittedly crude proxy for the generosity of pension system.

\section{Econometric strategy and results}

The first set of estimations is the basic specification of the empirical analysis. As explanatory variables, it contains the age-group specific upper secondary and tertiary educational attainment 
rate, the total female unemployment rate (women aged 15 to max), the share of female part-time employment in total female employment (women aged 15 to max), the share of seats in national parliament held by women, the logarithm of GDP and its square and the crude marriage and divorce rate. In order not to restrict the already small dataset even more, the basic regression excludes variables with missing values (i.e. public expenditure for pensions, public expenditure for child day care, duration of paid maternal leave and unadjusted gender paygap). The basic specification also excludes fertility as an explanatory variable. Due to potential endogeneity of fertility, this issue is addressed in a separate estimation. The variables included in the basic specification allow a sample of 301 observations for the age-groups between 25 and 59 and 287 observations for the age-group 60-64.

A concern when estimating the impact of education on female participation decisions is an omitted variable bias due to the potential correlation of education and unobserved cultural attitudes which are also likely to determine the female participation rate. But the inclusion of fixed effects in the regressions allows capturing cultural attitudes and thus minimizes the risk of bias from that source.

It is assumed that increasing divorce risk induces women to participate in the labor market to hedge against the possible income loss. However, it is also plausible that if the earnings of a women rise, she can decide more freely over marriage and divorce. The direction of causality is therefore ambiguous (Bremmer and Kesselring, 2004). One year lagged divorce and marriage rates are used to avoid biased estimates. ${ }^{18}$

With respect to the female unemployment rate and part-time work, the risk of a bias through reverse causality is taken into account by defining for both variables a larger age-group (women aged 15 to maximum instead of 25 to 64) (Genre et al., 2005; Jaumotte, 2003). Following the same argumentation, it is not expected that the age-group specific female participation rates do affect national GDP per capita to the extent that they cause a bias of the estimates.

A final concern relates to the structure of the dataset. Using annual data together with five-year age-groups implies that the female labor force moves in and out of each age-group over time. These slowly moving cohorts are likely to cause a moving average structure in the residuals. Because there is no lagged endogenous variable in the equation, there is no consistency problem, but a moving average structure of the residuals might cause a loss of efficiency.

\footnotetext{
${ }^{18}$ The value for the year 1995 corresponds to the actual value so as not to lose observations.
} 
The empirical analysis estimates a female participation for each age-group separately using Feasible Generalized Least Squares. The structure of the error term is corrected for heteroskedasticity. ${ }^{19}$ Each regression includes fixed effects. Table 2 reports the results for all age-groups.

Table 2: Fixed effect model - basic specification

Dependent variable: Female labor market participation rate

\begin{tabular}{|c|c|c|c|c|c|c|c|c|}
\hline Age-group & $25-29$ & $30-34$ & $35-39$ & $40-44$ & $45-49$ & $50-54$ & $55-59$ & $60-64$ \\
\hline Upper secondary education & $\begin{array}{l}0.463 * * * \\
(0.121)\end{array}$ & $\begin{array}{l}0.734 * * * \\
(0.146)\end{array}$ & $\begin{array}{l}1.000 * * * \\
(0.181)\end{array}$ & $\begin{array}{l}0.588 * * * \\
(0.159)\end{array}$ & $\begin{array}{l}0.120 \\
(0.151)\end{array}$ & $\begin{array}{l}-0.024 \\
(0.130)\end{array}$ & $\begin{array}{l}-0.656^{* * *} \\
(0.205)\end{array}$ & $\begin{array}{l}-0.113 \\
(0.344)\end{array}$ \\
\hline Tertiary education & $\begin{array}{l}0.519 * * * \\
(0.186)\end{array}$ & $\begin{array}{l}0.478 * * \\
(0.212)\end{array}$ & $\begin{array}{l}1.054 * * * \\
(0.226)\end{array}$ & $\begin{array}{l}0.831 * * * \\
(0.213)\end{array}$ & $\begin{array}{l}1.169^{* * *} \\
(0.218)\end{array}$ & $\begin{array}{l}1.503 * * * \\
(0.254)\end{array}$ & $\begin{array}{l}2.285^{* * * *} \\
(0.376)\end{array}$ & $\begin{array}{l}5.058 * * * \\
(0.576)\end{array}$ \\
\hline Total female unemployment rate & $\begin{array}{l}0.341 \\
(0.243)\end{array}$ & $\begin{array}{l}0.537 * * \\
(0.240)\end{array}$ & $\begin{array}{l}0.382^{*} \\
(0.208)\end{array}$ & $\begin{array}{l}-0.034 \\
(0.211)\end{array}$ & $\begin{array}{l}-0.342 \\
(0.228)\end{array}$ & $\begin{array}{l}-0.633 * * * \\
(0.184)\end{array}$ & $\begin{array}{l}0.248 \\
(0.202)\end{array}$ & $\begin{array}{l}-0.225 \\
(0.318)\end{array}$ \\
\hline $\begin{array}{l}\text { Share of total female } \\
\text { part-time employment }\end{array}$ & $\begin{array}{l}0.279 \\
(0.192)\end{array}$ & $\begin{array}{l}0.960 * * * \\
(0.202)\end{array}$ & $\begin{array}{l}1.295 * * * \\
(0.187)\end{array}$ & $\begin{array}{l}2.180 * * * \\
(0.177)\end{array}$ & $\begin{array}{l}2.147 * * * \\
(0.173)\end{array}$ & $\begin{array}{l}2.082 * * * \\
(0.182)\end{array}$ & $\begin{array}{l}1.996^{* * *} \\
(0.198)\end{array}$ & $\begin{array}{l}1.629 * * * \\
(0.362)\end{array}$ \\
\hline Share of women in parliament & $\begin{array}{l}0.102 \\
(0.184)\end{array}$ & $\begin{array}{l}0.720 * * * \\
(0.189)\end{array}$ & $\begin{array}{l}0.431 * * \\
(0.169)\end{array}$ & $\begin{array}{l}0.340 * * \\
(0.150)\end{array}$ & $\begin{array}{l}0.598 * * * \\
(0.148)\end{array}$ & $\begin{array}{l}0.062 \\
(0.166)\end{array}$ & $\begin{array}{l}-0.174 \\
(0.191)\end{array}$ & $\begin{array}{l}0.004 \\
(0.292)\end{array}$ \\
\hline Logarithm of GDP per capita & $\begin{array}{l}-3.039 * * * \\
(0.731)\end{array}$ & $\begin{array}{l}-5.405^{* * *} \\
(0.787)\end{array}$ & $\begin{array}{l}-4.926^{* * *} \\
(0.665)\end{array}$ & $\begin{array}{l}-2.574 * * * \\
(0.709)\end{array}$ & $\begin{array}{l}-3.646^{* * *} \\
(0.686)\end{array}$ & $\begin{array}{l}-3.328^{* * *} \\
(0.732)\end{array}$ & $\begin{array}{l}-3.499 * * * \\
(1.169)\end{array}$ & $\begin{array}{l}-4.067 * * \\
(1.589)\end{array}$ \\
\hline $\begin{array}{l}\text { Squared logarithm of } \\
\text { GDP per capita }\end{array}$ & $\begin{array}{l}0.163 * * * \\
(0.037)\end{array}$ & $\begin{array}{l}0.281 * * * \\
(0.041)\end{array}$ & $\begin{array}{l}0.248 * * * \\
(0.035)\end{array}$ & $\begin{array}{l}0.135 * * * \\
(0.037)\end{array}$ & $\begin{array}{l}0.201 * * * \\
(0.035)\end{array}$ & $\begin{array}{l}0.192 * * * \\
(0.037)\end{array}$ & $\begin{array}{l}0.217 * * * \\
(0.058)\end{array}$ & $\begin{array}{l}0.204 * * \\
(0.081)\end{array}$ \\
\hline Lagged crude marriage rate & $\begin{array}{l}0.551 \\
(0.638)\end{array}$ & $\begin{array}{l}-0.298 \\
(0.895)\end{array}$ & $\begin{array}{l}-1.988^{* * *} \\
(0.669)\end{array}$ & $\begin{array}{l}-2.901 * * * \\
(0.612)\end{array}$ & $\begin{array}{l}-1.464 * \\
(0.769)\end{array}$ & $\begin{array}{l}-2.319 * * * \\
(0.775)\end{array}$ & $\begin{array}{l}0.374 \\
(0.771)\end{array}$ & $\begin{array}{l}3.232 * * * \\
(0.856)\end{array}$ \\
\hline Lagged crude divorce rate & $\begin{array}{l}5.390 * * * \\
(2.034)\end{array}$ & $\begin{array}{l}15.189 * * * \\
(2.301)\end{array}$ & $\begin{array}{l}14.438 * * * \\
(2.133)\end{array}$ & $\begin{array}{l}10.092 * * * \\
(1.962)\end{array}$ & $\begin{array}{l}14.818^{* * *} \\
(1.961)\end{array}$ & $\begin{array}{l}16.754^{* * *} \\
(1.718)\end{array}$ & $\begin{array}{l}8.325 * * * \\
(2.022)\end{array}$ & $\begin{array}{l}7.214^{* *} \\
(3.102)\end{array}$ \\
\hline Constant & $\begin{array}{l}14.360 * * * \\
(3.583)\end{array}$ & $\begin{array}{l}25.250 * * * \\
(3.819)\end{array}$ & $\begin{array}{l}23.600 * * * \\
(3.197)\end{array}$ & $\begin{array}{l}11.445^{* * *} \\
(3.437)\end{array}$ & $\begin{array}{l}14.983 * * * \\
(3.354)\end{array}$ & $\begin{array}{l}12.254 * * * \\
(3.597)\end{array}$ & $\begin{array}{l}10.543^{*} \\
(5.835)\end{array}$ & $\begin{array}{l}18.634^{* *} \\
(7.785)\end{array}$ \\
\hline $\begin{array}{l}\text { Observations } \\
\text { Number of countries } \\
\text { Wald test: } \text { Prob }>\text { chi } 2\end{array}$ & $\begin{array}{l}301 \\
23 \\
0.0000 \\
\end{array}$ & $\begin{array}{l}301 \\
23 \\
0.0000 \\
\end{array}$ & $\begin{array}{l}301 \\
23 \\
0.0000 \\
\end{array}$ & $\begin{array}{l}301 \\
23 \\
0.0000 \\
\end{array}$ & $\begin{array}{l}301 \\
23 \\
0.0000 \\
\end{array}$ & $\begin{array}{l}301 \\
23 \\
0.0000 \\
\end{array}$ & $\begin{array}{l}301 \\
23 \\
0.0000 \\
\end{array}$ & $\begin{array}{l}287 \\
22 \\
0.0000 \\
\end{array}$ \\
\hline
\end{tabular}

Standard errors in parentheses

* significant at $10 \%$; * significant at $5 \% ; * * *$ significant at $1 \%$

The regressions are estimated using FGLS. Each regression includes country dummies.

Before starting the discussion of the results, one should note that, due to the interdependent relationship of educational attainment rates, increasing either upper secondary or tertiary education holding other included variables constant implies a lower value for the variable percentage with primary/lower secondary education as highest qualification obtained.

19 The variance of the error term in the logistic regession is

$$
\frac{1}{\left[N_{i} * F L P_{i}\left(1-F L P_{i}\right)\right]}
$$

As $F L P_{i}$ varies in the

explanatory variables, the variance is not constant. In this instance, OLS estimators are still unbiased but not efficient. Using weighted least squares estimators instead yields unbiased and efficient estimates (Aldrich and Nelson, 1984, p. 69). 
The results strongly indicate that the level of educational attainment has a strong impact on female labor force participation afor all age groups. The marginal effect of upper secondary education on female labor force participation is positive and highly significant up to the age 44 . For the age-group 45-49 the effect is still positive but no longer statistically significant. For the age-groups 50-54, 55-59 and 60-64 the coefficients turn negative, although they are only significant for the age-group 55-59.

The marginal effect of tertiary education is positive and statistically significant throughout all age-groups. For the age-group 30-34 the coefficient is significant at a 5 percent level; for all other age-groups, the coefficients are even significant at the 1 percent level. The difference between the signs of the coefficients of different education levels in the regressions of older agegroups is conspicuous. The results suggest that elderly women that achieved upper secondary education as highest educational level are more likely to drop out of the labor market while elderly women with tertiary education will continue to participate.

The size of the coefficients should be interpreted with caution. Because of the logistic transformation of the participation rate and the underlying non-linear relation with the explanatory variables, the impact of a change in one explanatory variable depends on the corresponding value of the explanatory variable. Calculating the impact of tertiary education for example for the age-groups 60-64 shows that increasing tertiary educational attainment by 10 percentage points translates in a mean increase in participation rates of 7 percent (ranging from 2 to 12 percent). Annex II shows the (partial) first order derivative of the female participation rate with respect to the tertiary educational attainment rate.

Table 2 also presents the effects of the other control variables on female participation. The total female unemployment rate gives mixed results. Its impact is negative for the age-groups 40-44, 45-49 50-54 and 60-64 but, the coefficient is significant only for the age-group 50-54. For the remaining (mostly younger) age-groups, the female unemployment rate has a positive effect and for the age-groups 30-34 and 35-39 the coefficient is statistically different from zero.

In contrast, the parameters of the share of female part-time employment as a proxy for the flexibility of working time arrangements have the expected positive sign and are (highly) significant, except for the age-group 25-29. Apparently the availability of part-time work is less important for women in their $20 \mathrm{~s}$, who have just started their professional career,. ${ }^{20}$

\footnotetext{
${ }^{20}$ This study only looks at the decision to participate in the labor market. Due to data limitations the analysis cannot distinguish between part-time and full-time participation. For studies including this distinction see e.g. Jaumotte (2003) or Bosch et al. (2005). In the study of Jaumotte, education has a significant positive effect on the aggregate
} 
The share of women in national parliaments, indicating the relative absence of female discrimination in the labor market, does enter positively and significantly for the age-groups between 30 and 49 . Even if the variable is only a rough proxy for gender discrimination in the labor market it does have explanatory power for the labor market behavior of prime age women, with signs as expected: more discrimination (less women in parliament) leads to lower participation rates.

The coefficients of the logarithm of GDP per capita and its square have to be interpreted together. For a U-shaped relationship of female labor force participation and economic growth, the logarithm of GDP per capita should be negative and its square positive (Luci, 2009). In all age-groups this pattern can be observed and the coefficients are significant at the 1 percent level for the age-groups up to 59 and at the 5 percent level for the age-group 60-64. Table 3 presents the threshold value of GDP per capita for each age-group after which a growth in GDP per capita causes a positive marginal reaction of female labor market participation. It shows that the values are increasing up to the age-group 35-39, after which they start declining up to the agegroup 55-59. The value jumps again for the age-group 60-64. One interpretation of this pattern could be that early childhood care systems are better developed in richer countries. Women that have small children (mostly women in the 30s) thus have a higher GDP threshold value. However, the extreme jump at the age 60 is surprising.

Table 3: GDP per capita threshold value

\begin{tabular}{|l|l|l|l|l|l|l|l|l|}
\hline Age-group & $\mathbf{2 5 - 2 9}$ & $\mathbf{3 0 - 3 4}$ & $\mathbf{3 5 - 3 9}$ & $\mathbf{4 0 - 4 4}$ & $\mathbf{4 5 - 4 9}$ & $\mathbf{5 0 - 5 4}$ & $\mathbf{5 5 - 5 9}$ & $\mathbf{6 0 - 6 4}$ \\
\hline $\begin{array}{l}\text { Minimum GDP per } \\
\text { capita (in current } \\
\text { international US\$) }\end{array}$ & 11182 & 15024 & 20567 & 13812 & 8687 & 5806 & 3172 & 21355 \\
\hline
\end{tabular}

The marginal effect of the (lagged) crude marriage rate is, as expected, negative for all agegroups between 25 and 54 but only significant for the age-groups between 35 and 54 . For the highest two age groups the coefficients turn positive and are even highly significant for the agegroup 60-64, which is something of a puzzle. The (lagged) crude divorce rate is positive throughout, as expected, and statistically significant at the 1 percent level up the age 59 and at the 5 percent level for the age-group 60-64.

female full-time participation rate and a significant negative effect on the aggregate female part-time participation rate. For the calculation of part-time and full-time female participation rates, Jaumotte assumes the same distribution between part-time and full-time for the labor supply as can be observed for employment. Similarly, in a study on labor market behavior of women in the Netherlands, Bosch et al. find that a woman is almost twice as likely to work full-time if she attained tertiary education compared to primary education. 
In a separate step, the unadjusted gender paygap as a further indicator for gender discrimination in the labor market is introduced into the regressions. However, the variable does not yield satisfying results. It is only significant in the age regressions 25-29 and 40-44 and in both cases unexpectedly positive. Interpreting these results as a positive reaction to discrimination might be rather misleading since it is not known if the paygap still holds after adjusting for skills. Unfortunately, the data for the adjusted gender gap are not available for most countries in the data sample.

The second set of estimations addresses the problem of the potential endogeneity of fertility. The causal relationship of fertility and labor market participation is ambiguous since getting children and participating in the labor market can be seen as a joint decision. Hence, fertility as a potentially endogenous variable involves the risk simultaneity bias (Bloom et al., 2009; Genre et al., 2005). Genre et al. (2005, p. 13) argue that "causality is more likely to go from fertility to participation because having children is a permanent decision, while participation is reversible, and therefore can adjust in the short run." In order to mitigate the risk of biased estimates, they use lagged fertility rates. Jaumotte (2003) reasons that for European countries there is no evidence of a negative impact of female participation decisions on fertility rates. Therefore, her empirical study does not include fertility in the regressions but policies that help reconciling work and family. The present empirical analysis tries nevertheless to take account of a possible endogeneity bias by instrumenting the fertility rate with child mortality under five. ${ }^{21}$ For technical reasons, the analysis refrains from a GLS correction at this point, although at the expense of efficiency of the estimates (cf. Aldrich and Nelson, 1984, p.69).

Empirical studies show that declining infant and child mortality is an important factor in explaining declining fertility rates (e.g. Eckstein et al., 1998). Parents apparently have a desire for a certain number of children. The consequent "precautionary demand" for children depends on the mortality rate of children. A higher expected mortality rate will according to this view lead to higher fertility rates to ensure that the desired number of children survives. KalemliOzcan (2008) also find that declining mortality rates lead to declining fertility rates. So empirical evidence seems to support the use of child mortality as an instrument for fertility rates. For each regression fertility is instrumented with child mortality under five. In all first stage regressions child mortality enters positively and statistically significant. In all estimations, the Fstatistic in the first stage exceeds 10 indicating that child mortality under five is not a weak

\footnotetext{
${ }^{21}$ Elhorst and Tanveer (2008) also usse child mortality as an instrument for fertility.
} 
instrument (Staiger and Stock, 1997). Table 4 presents the regression results for all age-groups including fertility as an explanatory variable.

Table 4: Fixed effect model - inclusion of total fertility rate as an explanatory variable

Dependent variable: Female labor market participation rate

\begin{tabular}{|c|c|c|c|c|c|c|c|c|}
\hline Age-group & $25-29$ & $30-34$ & 35-39 & $40-44$ & $45-49$ & $50-54$ & $55-59$ & $60-64$ \\
\hline Upper secondary education & $\begin{array}{l}0.417 * * * \\
(0.116)\end{array}$ & $\begin{array}{l}0.734 * * * \\
(0.141)\end{array}$ & $\begin{array}{l}0.979 * * * \\
(0.180)\end{array}$ & $\begin{array}{l}0.595^{* * *} \\
(0.160)\end{array}$ & $\begin{array}{l}0.122 \\
(0.149)\end{array}$ & $\begin{array}{l}-0.051 \\
(0.133)\end{array}$ & $\begin{array}{l}-0.785^{* * *} \\
(0.208)\end{array}$ & $\begin{array}{l}-0.307 \\
(0.343)\end{array}$ \\
\hline Tertiary education & $\begin{array}{l}0.474 * * * \\
(0.180)\end{array}$ & $\begin{array}{l}0.508^{* *} \\
(0.209)\end{array}$ & $\begin{array}{l}1.003 * * * \\
(0.229)\end{array}$ & $\begin{array}{l}0.847 * * * \\
(0.213)\end{array}$ & $\begin{array}{l}1.146^{* * * *} \\
(0.216)\end{array}$ & $\begin{array}{l}1.426 * * * \\
(0.267)\end{array}$ & $\begin{array}{l}1.988^{* * * *} \\
(0.386)\end{array}$ & $\begin{array}{l}5.213^{* * *} \\
(0.545)\end{array}$ \\
\hline Total female unemployment rate & $\begin{array}{l}0.092 \\
(0.257)\end{array}$ & $\begin{array}{l}0.338 \\
(0.251)\end{array}$ & $\begin{array}{l}0.221 \\
(0.230)\end{array}$ & $\begin{array}{l}-0.143 \\
(0.221)\end{array}$ & $\begin{array}{l}-0.229 \\
(0.235)\end{array}$ & $\begin{array}{l}-0.575^{* * *} \\
(0.196)\end{array}$ & $\begin{array}{l}0.666^{* * * *} \\
(0.217)\end{array}$ & $\begin{array}{l}0.025 \\
(0.348)\end{array}$ \\
\hline $\begin{array}{l}\text { Share of total female } \\
\text { part-time employment }\end{array}$ & $\begin{array}{l}0.310^{*} \\
(0.188)\end{array}$ & $\begin{array}{l}1.027 * * * \\
(0.203)\end{array}$ & $\begin{array}{l}1.295^{* * *} \\
(0.189)\end{array}$ & $\begin{array}{l}2.150 * * * \\
(0.174)\end{array}$ & $\begin{array}{l}2.139 * * * \\
(0.173)\end{array}$ & $\begin{array}{l}2.090 * * * \\
(0.182)\end{array}$ & $\begin{array}{l}1.972 * * * \\
(0.202)\end{array}$ & $\begin{array}{l}1.627 * * * \\
(0.364)\end{array}$ \\
\hline Share of women in parliament & $\begin{array}{l}0.047 \\
(0.181)\end{array}$ & $\begin{array}{l}0.786^{* * *} \\
(0.185)\end{array}$ & $\begin{array}{l}0.458^{* * * *} \\
(0.171)\end{array}$ & $\begin{array}{l}0.366^{* *} \\
(0.151)\end{array}$ & $\begin{array}{l}0.566^{* * *} \\
(0.149)\end{array}$ & $\begin{array}{l}0.071 \\
(0.166)\end{array}$ & $\begin{array}{l}-0.114 \\
(0.191)\end{array}$ & $\begin{array}{l}0.018 \\
(0.289)\end{array}$ \\
\hline Logarithm of GDP per capita & $\begin{array}{l}-3.130 * * * \\
(0.737)\end{array}$ & $\begin{array}{l}-5.568 * * * \\
(0.793)\end{array}$ & $\begin{array}{l}-5.094 * * * \\
(0.687)\end{array}$ & $\begin{array}{l}-2.781 * * * \\
(0.723)\end{array}$ & $\begin{array}{l}-3.540 * * * \\
(0.673)\end{array}$ & $\begin{array}{l}-3.345^{* * * *} \\
(0.731)\end{array}$ & $\begin{array}{l}-3.647^{* * *} \\
(1.196)\end{array}$ & $\begin{array}{l}-3.647 * * \\
(1.568)\end{array}$ \\
\hline $\begin{array}{l}\text { Squared logarithm of } \\
\text { GDP per capita }\end{array}$ & $\begin{array}{l}0.169 * * * \\
(0.038)\end{array}$ & $\begin{array}{l}0.289 * * * \\
(0.041)\end{array}$ & $\begin{array}{l}0.257 * * * \\
(0.036)\end{array}$ & $\begin{array}{l}0.146^{* * *} \\
(0.037)\end{array}$ & $\begin{array}{l}0.196 * * * \\
(0.034)\end{array}$ & $\begin{array}{l}0.193 * * * \\
(0.037)\end{array}$ & $\begin{array}{l}0.226^{* * *} \\
(0.060)\end{array}$ & $\begin{array}{l}0.182 * * \\
(0.080)\end{array}$ \\
\hline Lagged crude marriage rate & $\begin{array}{l}0.268 \\
(0.598)\end{array}$ & $\begin{array}{l}-0.165 \\
(0.821)\end{array}$ & $\begin{array}{l}-2.176^{* * * *} \\
(0.690)\end{array}$ & $\begin{array}{l}-2.801 * * * \\
(0.581)\end{array}$ & $\begin{array}{l}-1.701 * * \\
(0.781)\end{array}$ & $\begin{array}{l}-2.341 * * * \\
(0.777)\end{array}$ & $\begin{array}{l}0.110 \\
(0.738)\end{array}$ & $\begin{array}{l}2.878 * * * \\
(0.885)\end{array}$ \\
\hline Lagged crude divorce rate & $\begin{array}{l}4.769 * * \\
(1.972)\end{array}$ & $\begin{array}{l}14.165 * * * \\
(2.306)\end{array}$ & $\begin{array}{l}14.187 * * * \\
(2.174)\end{array}$ & $\begin{array}{l}9.907 * * * \\
(1.983)\end{array}$ & $\begin{array}{l}14.872 * * * \\
(1.958)\end{array}$ & $\begin{array}{l}16.718^{* * * *} \\
(1.716)\end{array}$ & $\begin{array}{l}7.916^{* * *} \\
(1.953)\end{array}$ & $\begin{array}{l}7.361 * * \\
(3.306)\end{array}$ \\
\hline Total fertility rate & $\begin{array}{l}-0.218^{* * * *} \\
(0.080)\end{array}$ & $\begin{array}{l}-0.243^{* * *} \\
(0.090)\end{array}$ & $\begin{array}{l}-0.128 \\
(0.088)\end{array}$ & $\begin{array}{l}-0.123^{*} \\
(0.074)\end{array}$ & $\begin{array}{l}0.150^{*} \\
(0.082)\end{array}$ & $\begin{array}{l}0.077 \\
(0.087)\end{array}$ & $\begin{array}{l}0.365^{* * *} \\
(0.101)\end{array}$ & $\begin{array}{l}0.311 * * \\
(0.129)\end{array}$ \\
\hline Constant & $\begin{array}{l}15.054 * * * \\
(3.623)\end{array}$ & $\begin{array}{l}26.516^{* * * *} \\
(3.877)\end{array}$ & $\begin{array}{l}24.623 * * * \\
(3.338)\end{array}$ & $\begin{array}{l}12.646^{* * * *} \\
(3.530)\end{array}$ & $\begin{array}{l}14.279 * * * \\
(3.296)\end{array}$ & $\begin{array}{l}12.186^{* * *} \\
(3.591)\end{array}$ & $\begin{array}{l}10.472^{*} \\
(5.953)\end{array}$ & $\begin{array}{l}16.290^{* *} \\
(7.700)\end{array}$ \\
\hline Observations & 301 & 301 & 301 & 301 & 301 & 301 & 301 & 287 \\
\hline Number of countries & 23 & 23 & 23 & 23 & 23 & 23 & 23 & 22 \\
\hline Wald test: Prob $>$ chi 2 & 0.0000 & 0.0000 & 0.0000 & 0.0000 & 0.0000 & 0.0000 & 0.0000 & 0.0000 \\
\hline
\end{tabular}

To test whether the OLS or IV regression technique is appropriate, we apply the Hausman test to each regression in order (Wooldridge, 2002). The Hausman test generates an F-Statistic with the null hypothesis that there are no systematic differences in the coefficients of the OLS (efficient estimation) and the IV (consistent estimation) regression. For all regressions, the null hypothesis 
cannot be rejected, indicating that the OLS estimates are appropriate. ${ }^{22}$ Table A3 in the Annex shows the results of the Hausman test. ${ }^{23}$

Fertility enters negatively up to the age 44 and turns positive for the age-groups between 45 and 64 and is significant for the age-groups 25-29, 30-34, 40-44, 45-49, 55-59 and 60-64. In a way the high significance levels for the elderly age-groups are surprising since the total fertility rate is only defined over the fertile life of a woman. The results indicate that with a higher total fertility rate, other things being equal, the distribution of female labor market participation is skewed towards the elderly which could be taken as negative social attitudes towards working mothers, and an 'intergenerational division of labor'.

In order to examine the effect of elderly women's own fertility rates, the regressions for the agegroups $45-49,50-54,55-59$ and 60-64 are re-estimated using past fertility rates matching each age group. For the age-group 45-49 the period refers to the years 1975-1988, for the age-group 50-54 to the years 1970 to 1983, for the age-group 55-59 to the years 1965 to 1978 and for the age-group 60-64 to the years 1960 to 1973, i.e. to the peak fertile years of women of the respective age-group. It turns out that the inclusion of past fertility rates changes the coefficients in the expected direction. The coefficient of the age-groups 45-49, 50-54 and 60-64 turn negative and are highly significant. The fertility rate of the age-group 55-59 loses significance. The results suggest that the effect of "own" fertility is not just temporary but that it triggers a persistent negative effect on participation rates of women over their entire life time. This could be interpreted as a 'hysteresis effect of fertility'. Table 5 presents the results for the four agegroup regressions.

The results for the educational variables from the basic model are robust to the inclusion of both concurrent and "own" fertility rates. In the regressions of the age-groups 45-49 and 50-54 with past fertility rates, the signs of upper secondary education change but stay insignificant. In all remaining age-group regressions the signs and significance levels of both education levels remain unchanged.

With respect to the control variables, it is noticeable that, for many age-groups, the empirical results of the total female unemployment rate shows changed signs and/or significance levels once fertility rates are included. This may be due to a correlation between fertility and the female unemployment rate. However, it is also possible that the choice of the total female

\footnotetext{
${ }^{22}$ The Hausman test is conducted for every estimation that follows. In all cases the null hypotheses stating no systematic differences between the OLS and IV estimates cannot be rejected.

${ }^{23}$ However, it should be kept in mind that the Hausman test depends on the choice of the instrument (Jordahl et al., 2009) and the risk of potential bias is not entirely precluded.
} 
unemployment rate instead of the age-group specific female unemployment rate does not totally solve the issue of endogeneity of unemployment and the associated potential feedbacks of the participation rate on unemployment (Genre et al., 2005).

Table 5: Fixed effect model - re-estimation for the age-groups 45-49, 50-54, $55-59$ and $60-64$ with past fertility

Dependent variable: Female labor market participation rate

\begin{tabular}{|c|c|c|c|c|}
\hline Age-group & $45-49$ & $50-54$ & $55-59$ & $60-64$ \\
\hline Upper secondary education & $\begin{array}{l}-0.080 \\
(0.149)\end{array}$ & $\begin{array}{l}0.012 \\
(0.143)\end{array}$ & $\begin{array}{l}-0.582 * * * \\
(0.225)\end{array}$ & $\begin{array}{l}-0.069 \\
(0.321)\end{array}$ \\
\hline Tertiary education & $\begin{array}{l}1.044^{* * *} \\
(0.202)\end{array}$ & $\begin{array}{l}1.278 * * * \\
(0.253)\end{array}$ & $\begin{array}{l}2.123 * * * \\
(0.430)\end{array}$ & $\begin{array}{l}2.214 * * * \\
(0.686)\end{array}$ \\
\hline Total female unemployment rate & $\begin{array}{l}0.316 \\
(0.207)\end{array}$ & $\begin{array}{l}-0.298 \\
(0.186)\end{array}$ & $\begin{array}{l}0.229 \\
(0.252)\end{array}$ & $\begin{array}{l}-1.008^{* * * *} \\
(0.260)\end{array}$ \\
\hline $\begin{array}{l}\text { Share of total female } \\
\text { part-time employment }\end{array}$ & $\begin{array}{l}2.199 * * * \\
(0.168)\end{array}$ & $\begin{array}{l}1.695 * * * \\
(0.190)\end{array}$ & $\begin{array}{l}1.985^{* * *} \\
(0.239)\end{array}$ & $\begin{array}{l}1.463 * * * \\
(0.321)\end{array}$ \\
\hline Share of women in parliament & $\begin{array}{l}0.487 * * * \\
(0.136)\end{array}$ & $\begin{array}{l}-0.06 \\
(0.170)\end{array}$ & $\begin{array}{l}-0.174 \\
(0.217)\end{array}$ & $\begin{array}{l}-0.198 \\
(0.259)\end{array}$ \\
\hline Logarithm of GDP per capita & $\begin{array}{l}-3.558^{* * *} \\
(0.636)\end{array}$ & $\begin{array}{l}-2.964 * * * \\
(0.734)\end{array}$ & $\begin{array}{l}-3.241 * * * \\
(1.186)\end{array}$ & $\begin{array}{l}-0.781 \\
(1.611)\end{array}$ \\
\hline $\begin{array}{l}\text { Squared logarithm of } \\
\text { GDP per capita }\end{array}$ & $\begin{array}{l}0.193 * * * \\
(0.032)\end{array}$ & $\begin{array}{l}0.171 * * * \\
(0.037)\end{array}$ & $\begin{array}{l}0.204 * * * \\
(0.060)\end{array}$ & $\begin{array}{l}0.043 \\
(0.082)\end{array}$ \\
\hline Lagged marriage rate & $\begin{array}{l}-1.509 * \\
(0.817)\end{array}$ & $\begin{array}{l}-1.879 * * \\
(0.785)\end{array}$ & $\begin{array}{l}0.443 \\
(0.801)\end{array}$ & $\begin{array}{l}3.975 * * * \\
(0.846)\end{array}$ \\
\hline Lagged divorce rate & $\begin{array}{l}5.058 * * \\
(2.026)\end{array}$ & $\begin{array}{l}12.185 * * * \\
(1.877)\end{array}$ & $\begin{array}{l}7.903 * * * \\
(2.350)\end{array}$ & $\begin{array}{l}7.956^{* * * *} \\
(2.430)\end{array}$ \\
\hline Total fertility rate 20 years ago & $\begin{array}{l}-0.309 * * * \\
(0.032)\end{array}$ & & & \\
\hline Total fertility rate 25 years ago & & $\begin{array}{l}-0.237 * * * \\
(0.042)\end{array}$ & & \\
\hline Total fertility rate 30 years ago & & & $\begin{array}{l}-0.001 \\
(0.048)\end{array}$ & \\
\hline Total fertility rate 35 years ago & & & & $\begin{array}{l}-0.549 * * * \\
(0.070)\end{array}$ \\
\hline Constant & $\begin{array}{l}16.537 * * * \\
(3.162)\end{array}$ & $\begin{array}{l}12.546^{* *} \\
(3.666)\end{array}$ & $\begin{array}{c}10.365^{*} \\
(5.948)\end{array}$ & $\begin{array}{l}2.745 \\
(7.917)\end{array}$ \\
\hline Observations & 301 & 301 & 301 & 287 \\
\hline Number of countries & 23 & 23 & 23 & 22 \\
\hline Wald test: Prob $>$ chi 2 & 0.0000 & 0.0000 & 0.0000 & 0.0000 \\
\hline
\end{tabular}

The analysis until now assumes that effects of external variables may differ across age groups, but assumes that all cohorts behave the same once they reach a particular age group. But changing social mores may lead to different behaviour for younger cohorts. If they react 
stronger to such changes they might show higher participation at any age compared to the participation rates of the preceding cohorts (Balleer et al., 2009, Fallick and Pingle, 2007). To capture possible cohort effects, a dummy indicating if women are born after 1965 is introduced into the regressions. ${ }^{24}$ The use of age-groups in five year increments poses some difficulties in this context as the age-groups move only gradually from the time before the cut-off year to the time after. For example in 1997, only those women in the age-group 30-34 that are 30 or 31 were born after 1965. In order to use as much of the available information as possible, the cohort dummy is constructed as a fractional dummy with values between 0 and 1 if the birth year of the five year cohort is as it were moving past the cut off year. For example for the 30-34 age-group, the fractional dummy takes a value 0,4 in 1997: in 1997 only 2 out of 5 years (40\%) of the then 30-34 year cohort were born after 1965 .

However, the inclusion of the cut-off dummy does not yield clear results. It enters positively and statistically significant for the age-groups 30-34 but is negative and not statistically different from zero in the 35-39 and 40-44 age-group regressions. For the remaining age-groups, the dummy value is either always zero or one, so we cannot test the impact of the dummy.

Table 6: Results fractional cohort dummy

\begin{tabular}{|l|l|l|l|l|}
\hline $\begin{array}{l}\text { Cut-off } \\
\text { year }\end{array}$ & Age-group 25-29 & Age-group 30-34 & Age-group 35-39 & Age-group 40-44 \\
\hline $\mathbf{1 9 6 5}$ & -- & positive, significant*** & $\begin{array}{l}\text { negative, } \\
\text { not significant }\end{array}$ & positive, not significant \\
\hline $\mathbf{1 9 7 0}$ & positive, significant** & $\begin{array}{l}\text { negative, } \\
\text { significant*** }\end{array}$ & positive, significant** & -- \\
\hline $\mathbf{1 9 7 5}$ & $\begin{array}{l}\text { negative, } \\
\text { not significant }\end{array}$ & $\begin{array}{l}\text { negative, } \\
\text { not significant }\end{array}$ & -- & -- \\
\hline
\end{tabular}

Taking 1970 as cut-off year does not provide more conclusive results. Now the cohort dummy enters positively and significantly for the age-groups 25-29 and 35-39, but negatively and significantly for the age-group 30-34. Similarly, 1975 as cut-off years does not provide conclusive results either. Table 6 gives an overview of the effect of different cut-off years for the cohort dummy. The results suggest that a certain cohort dynamic exists but that the small data sample does not allow capturing it effectively. For all three specifications, the education results remain robust. ${ }^{25}$

\footnotetext{
${ }^{24}$ Balleer et al. (2009) study age and cohort effects on labor force participation in the Euro area. They find that women that are born in the 1920s and 1930s are less likely to go into the labor market compared to women born in the late 1960s and early 1970s.

${ }^{25}$ With respect to the inclusion of the cohort dummy with 1965 as cut-off year, the significance level of tertiary education in the 30-34 age-group changes from 5 percent to 1 percent. With respect to the cohort dummy with 1970
} 
Table A4 and A5 in the Annex show the estimation results including the cohort dummy with the cut-off year 1965 and the cut-off year 1970, respectively.

The third set of estimations includes age-group specific policy variables in the regressions; because of data availability problems, this comes at the cost of a significantly reduced sample size.

For the age-groups between 25 and 49, the regressions include the duration of paid maternal leave and public expenditure for formal child day care in percent of GDP. For the age-group 4549 we try to capture the effect of family policies by including the fertility rates five years ago, the maternal leave duration from these years ${ }^{26}$ and actual child day care expenditures ${ }^{27}$. The inclusion of family policies reduces the sample size to a number of 218 observations because of data availability problems. ${ }^{28}$

For the age-groups 50-54, 55-59 and 60-64 the expenditure for old age pension benefits (in percent of GDP) is included in the regressions. The inclusion of the new variable decreases the number of observations to 246 in the 50-54 and 55-59 age-group regression and to 234 in the 60-64 age-group regression. ${ }^{29}$

Overall, the policy variables are only of moderate significance. This may, however, be due to the reduced number of observation in the already small data sample. Furthermore, it proves to be difficult to find suitable proxies for social policies. For example, the variable expenditure for old age benefits as a proxy for the generosity of the pension system does not include information about early retiremnt incentives that may be embedded in the pension system. The results have therefore to be treated with some reservation.

The duration of paid maternal leave is only significant for the 30-34 age-group. For women at these ages, an increase in the duration of paid maternal leave has a positive effect on

\footnotetext{
as cut-off year, the significance level of tertiary education in the 25-29 changes from 1 percent to 5 percent and in the 30-34 age-group the level changes again from 5 percent to 1 percent.

${ }^{26}$ If values before 1995 are missing, maternal leave data are linearly interpolated and extrapolated.

${ }^{27}$ As childcare expenditure are defined for children at pre-school age. For a definition of the variable see table A1 in the Annex.

${ }^{28}$ For Ireland, Slovakia and Poland the data for the expenditure on formal child day care are not available.

${ }^{29}$ Because of the inconsistencies of the education data of the age-group 60-64 in United Kingdom.
} 
participation, however just up to a length of 17 weeks. ${ }^{30}$ The expenditure for child day care has a significant and encouraging effect for the age-groups 35-39 and 45-49. ${ }^{31}$

The expenditure for old age pensions shows the expected negative (and significant) sign in the 55-59 age-group regression only. For the age-groups 50-54 the coefficient is positive and significant while for the age-group 60-64 the effect is positive but not significantly different from zero.

Despite the reduced data sample, the results of the education variable remain robust. ${ }^{32}$ Table A6 and A7 in the Annex present the results for prime-age women and elderly women, respectively.

\section{Educational progress, aging and female labor market participation}

The previous section showed that educational attainment levels influence the participation decisions of women at all ages. Upper secondary education has a positive impact up to the agegroup 45-49 and except for this age-group the variable shows significant coefficients. After that age, the marginal effect of an increase in upper secondary education turns negative and is significant for the age-group 55-59. Increasing tertiary education, however, has a positive and significant impact throughout all age groups.

What do these results mean for aggregate future participation rates? The demographic transition that is underway globally implies that the composition of the working age population will shift towards the elderly. In order to nevertheless reach an increase in the aggregate participation rate, age-group specific participation rates have to increase enough to compensate for the aggregate effect of lower participation rates of the elderly.

This section simulates a fictional but not impossible scenario for participation rates in 2050: what would regionwide participation rates look like if all countries would reach the same educational status as Sweden now (2008). We do this in two steps. First we use the econometric results to simulate the participation effects of all age groups reaching educational achievement levels currently attained by the 25-29 cohort in Sweden. These simulations indicate the potential for higher participation rates if educational achievement levels would rise throughout

\footnotetext{
${ }^{30}$ This value is very low compared to the finding of Genre et al. (2005) where the maternal leave duration has a positive impact on female participation up to a length of 10 months.

${ }^{31}$ It would be equally interesting to examine the effect of family policies at the time when the elderly age-groups were young on their labor force participation in their older ages in order to learn if family friendly policies can initiate a continuing effect on labor market participation. Unfortunately this data are not available.

${ }^{32}$ In fact, compared to the basic regression, upper secondary education in the 50-54 age-group changes sign but stays insignificant. Furthermore, the significance level of upper secondary education in the 55-59 age-group regression changes from the 1 to the 5 percent level and similarly for tertiary education in the 25-29 age-group regression.
} 
the EU to the high level currently attained by the 25-29 cohorts in Sweden. If feasible at all such a quantum leap is of course only achievable over a protracted time perod; therefore in our second round of simulations we assume it takes until 2050 to reach these levels throughout the EU and assess to what extent higher educational levels help in offsetting the negative impact on labor force participation of the shift from young to old that is widely expected over those years.

Consider the pure educational achievement effects first. We compare predicted participation rates per cohort per country for the year 2008 and use the actual age distribution to aggregate the results in a single number per country for female labor force participation. To offset credit crisis effects we evaluate using 2006 values for unemployment and per capita GDP.

Table 7: participation effects of higher educational achievement levels (towards Sweden's current 25-29 cohort's levels)

country

$\begin{array}{ll}\text { Austria } & 5.3 \% \\ \text { Belgium } & 3.6 \% \\ \text { Cyprus } & 5.1 \% \\ \text { Czech Republic } & 5.0 \% \\ \text { Denmark } & 2.8 \% \\ \text { Finland } & 2.0 \% \\ \text { France } & 4.5 \% \\ \text { Germany } & 4.4 \% \\ \text { Greece } & 6.4 \% \\ \text { Hungary } & 4.8 \% \\ \text { Ireland } & 4.3 \% \\ \text { Italy } & 7.1 \% \\ \text { Latvia } & 3.4 \% \\ \text { Luxembourg } & 5.4 \% \\ \text { Netherlands } & 4.3 \% \\ \text { Poland } & 5.8 \% \\ \text { Portugal } & 7.1 \% \\ \text { Romania } & 6.8 \% \\ \text { Slovakia } & 3.8 \% \\ \text { Slovenia } & 4.1 \% \\ \text { Spain } & 6.0 \% \\ \text { Sweden } & 1.9 \% \\ \text { United Kingdom } & 2.6 \%\end{array}$


The table shows substantial potential gains from upgrading educational achievement. A low $2 \%$ in Sweden itself (the difference between younger and older cohorts is apparently modest), but for some other countries reaching the same level could yield some 7 percentage points extra female labor force participation. Weighted by shares in total working age population, the average goes up by a very substantial $4,9 \%$.

Consider now the next step, to what extent does this potential increase in female labor force participation offset the negative impact one may expect from the demographic transition, with its consequence, an aging population.

We do so by substituting predictions of the future values of the explanatory variables into the empirical model to forecast age specific participation rates for 2050. These cohort predictions are then weighted with the predicted 2050 age-structure to calculate aggregate participation rates. The following assumptions are made. As benchmark values for education in 2050, we again take Sweden's educational attainment rates from the age-group 25-29 in 2008 and applys them to all age-groups in all countries. That is to say, in 2050, only 8.6 percent women at any age and country will have achieved at most primary/lower secondary education, 47.2 percent of women will have achieved at most upper secondary education and 45.9 percent will have achieved tertiary education.

For GDP per capita, we assume that the EU-15 countries grow throughout with an annual growth rate of 1.5 percent. 2006 is chosen as the base year for GDP per capita to avoid crisis biased estimates. For the new member states, a 2.9 percent growth rate is chosen as a starting value that converges to 1.5 percent by 2050 . The female unemployment rate is assumed to be constant (at 2006 values) until 2050. For the remaining explanatory variables, the 2008 values are taken and also assumed to be constant until 2050. The long-term population projections are taken from the UN-Population Division (2005) that provides demographic projections until 2050 .

The assumed educational attainment rates would imply drastic changes in the educational distribution for some countries and might not be feasible for some countries until much later than 2050. For example in Portugal, 45.9 percent of women in the age-group 60-64 would have achieved tertiary education in 2050 compared to 7.4 percent in 2008 . To show the dimension of the implied changes in educational attainment rates, Table A8 in the Annex presents the educational attainment rates for all age-groups and countries in 2008.

Also, projections for the age-structure in 2050 contain a lot of uncertainty (Van Ewijk et al., 2006). Still we do think that the simulations provide important information for policy 
makers. If improving the educational attainment of women contributes significantly to raising aggregate participation rates, policies promoting female education might help to counteract the detrimental impact of demographic change. This is particularly important for the PAYG pension systems in Europe. The results for 2050 show increases in participation rates for all age-groups. Weighting these rates with the 2050 age-structure, however, decreases the effect on the aggregate participation rate because of the increasing proportion of elderly women in the total female working population in 2050 compared to 2008.

Table 8: Predicted increase of participation rates between 2008 and 2050

\begin{tabular}{|c|c|c|c|}
\hline Country & \begin{tabular}{|l} 
A: \\
Increase with 2050 \\
weights
\end{tabular} & $\begin{array}{l}\text { B: } \\
\text { Increase with } 2008 \\
\text { weights } \\
\end{array}$ & $\begin{array}{l}\text { C: } \\
\text { A-B = Aging Effec }\end{array}$ \\
\hline Austria & 0.043 & 0.097 & -0.054 \\
\hline Belgium & 0.026 & 0.042 & -0.016 \\
\hline Cyprus & 0.059 & 0.124 & -0.065 \\
\hline Czech Republic & 0.040 & 0.086 & -0.046 \\
\hline Denmark & 0.056 & 0.054 & 0.002 \\
\hline Finland & 0.049 & 0.041 & 0.008 \\
\hline France & 0.075 & 0.082 & -0.007 \\
\hline Germany & 0.032 & 0.077 & -0.046 \\
\hline Greece & 0.079 & 0.120 & -0.041 \\
\hline Hungary & 0.112 & 0.154 & -0.042 \\
\hline Ireland & 0.083 & 0.138 & -0.055 \\
\hline Italy & 0.096 & 0.124 & -0.027 \\
\hline Latvia & -0.021 & 0.072 & -0.093 \\
\hline Luxembourg & 0.084 & 0.122 & -0.038 \\
\hline Netherlands & 0.073 & 0.086 & -0.013 \\
\hline Poland & 0.031 & 0.104 & -0.073 \\
\hline Portugal & 0.070 & 0.105 & -0.034 \\
\hline Romania & 0.028 & 0.107 & -0.079 \\
\hline Slovakia & -0.013 & 0.083 & -0.096 \\
\hline Slovenia & 0.048 & 0.106 & -0.058 \\
\hline Spain & 0.082 & 0.123 & -0.041 \\
\hline Sweden & 0.029 & 0.041 & -0.012 \\
\hline United Kingdom & 0.040 & 0.063 & -0.023 \\
\hline Total weighted increase & 0.060 & 0.094 & \begin{tabular}{|l|}
-0.034 \\
\end{tabular} \\
\hline
\end{tabular}

We present the results in two steps. In the column A of Table 7, we show the increase per country of reaching Swedish educational attainment levels at 2050 population weights. To disentangle the relative impact of changing population weight and changes in educational attainment levels, we next show aggregate participation rates aggregated up using 2008 population weights (column B). Column B represents the pure impact of the presumed improvement in educational attainment levels. The difference between columns B and A is due to changing population weights and is what we call the aging effect. 
The table shows an overall, population weighted increase of 6\%. Latvia and Slovakia would actually see participation rates fall, all other countries would see sometimes substantial increases in female labor market participation, between 2.6 percentage points in Belgium and 11.2 percentage points in Hungary.

Column B shows the pure education impact, evaluating the impact of higher educational achievements at 2008 population weights. The aggregate effect is substantially higher, at a population weighted average of 9.4\%, ranging from a low $4.1 \%$ (Finland, Belgium and Sweden itself) to a massive $15.4 \%$ increase in Hungary. Educational policies, if at least they can be made effective, thus promise very substantial increases in participation rates.

In Column $\mathrm{C}$, the aging effect is calculated by subtracting column B from column A. It shows that the aging effect on the increase in participation rates is strongly negative, reducing the overall impact of educational improvement by $3.4 \%$ (from 9.4 to $6.0 \%$ ). That is, the aging effect would reduce the increase in aggregate participation rates across the countries in the sample by one third. The negative impact of adverse shifts in the age distribution is particularly strong in Eastern Europe, as can be seen in column C. For instance, for the two negative overall performers, Slovakia would show an aggregate increase in participation of 8.3 percentage points with a fixed 2008 age-structure compared to a 1.3 decrease with an age-structure based on 2050 values. For Latvia, the other negative overall performer, a pure educational increase of $7.2 \%$ would be more than reversed by a strongly negative aging effect of $-9.4 \%$

\section{Conclusion}

We started out asking two questions: do educational attainment levels influence the labor market participation behavior of women and to what extent does the impact depend on the age group concerned? In order to answer these questions, we estimated separate female labor market participation equations for eight age-groups of five years each between 25 and 64 years, based on a panel of 23 EU countries over the period 1995 to 2008. The use of annual educational attainment data that differentiate not only for gender but also between age-groups allowed for more reliable estimates of the effect of the educational attainment level on women's participation decisions at different life stages.

The study finds evidence of a significant and positive effect of higher (tertiary) education on participation rates of women in every age group. The attainment of upper secondary education 
only has an encouraging effect on women up to an age of 40 while after that age it does not seem to play a significant role in participation decisions. It even appears to have a significantly negative impact on participation decisions of the age-group 55-59.

Along with the results on the education variables, the analysis shows other interesting results too. Including concurrent fertility rates shows a strongly negative impact on participation rates for women in age groups 25-29, 30-34, 35-39 and 40-44. For higher age groups the effect turns positive, and significantly so for the oldest two groups. This somewhat puzzling result disappears once we include a cohort's own fertility rate, i.e. the fertility rate that obtained in aggregate when the cohort was in its most fertile period of life. Now fertility exerts a strongly and significantly negative effect on labor force participation across all age groups.

We do not find strong discouraged worker effects; participation rates increase in response to higher female unemployment for the younger cohorts (although the coefficients are not significant), but decrease for middle aged cohorts and increase again for the oldest cohorts. There is some evidence of discrimination in that our (inverse) proxy for that, share of women elected to parliament, shows up significantly and with the expected sign for most age groups. Marriage rates decrease participation, but divorce rates have a strongly positive impact on labor force participation by women, as one would expect given the financial consequences of divorce.

The findings of the effect of the educational attainment level on women's participation decisions at different life stages are very relevant for the current discussions on the impact of the aging of the European population. The results indicate that policies aiming to increase access to in particular tertiary education is likely to have a strong stimulating effect on long-term labor market participation rates. An increase in participation rates could help to attenuate the downward pressure on economic growth and fiscal sustainability in European countries posed by the aging population.

A simulated scenario for 2050 explores the consequence of an extreme ambition: all countries and all cohorts reach the level of educational acchievement currently attained by the youngest age group considered (25-29) in Sweden. We show that such an upward shift in educational achievement would in itself increase female labor market participation by more than 9 percentage points ( 9.4 to be precise). That such policies are necessary also comes out of our simulation: aging itself will lower aggregate participation rates by 6 percentage points. The impact of aging will be felt most harshly in Eastern Europe, where in 2 countries aging effects are strong enough to more than reverse the positive impact of educational improvements. 


\section{Bibliography}

Aldrich, J.H. and F.D. Nelson (1984). Linear probability, logit, and probit models; SAGE Publication: Beverly Hills, California.

Balleer, A., R. Gomez-Salvador and J. Turunen (2009). Labour force participation in the Euro Area - a cohort based analysis; ECB Working paper Series no. 1049.

Ballasone, F.; C. Cunha, G. Langenus, B. Manzke, J. Pavot, D. Prammer, P. Tommasino (2009). Fiscal sustainability and policy implications for the Euro area; ECB Working Paper Series no. 994.

Barro, R.J. and J. Lee (2001). International data on educational attainment: update and implications; Oxford Economic Papers 53 (3), pp. 541-563.

Bloom, D.E., D. Canning and G. Fink (2009). Fertility, female labor force participation, and the demographic dividend; Journal for Economic Growth 14 (2), pp. 79-101.

Bosch, N., A. Deelen and R. Euwals (2008). Is part-time employment here to stay? Evidence from the Dutch Labor Force Survey 1992-2005; IZA Discussion Paper no. 3367.

Boeri, T. (2005). The Lisbon process and European women at work, Paper prepared for the Conference political Economy and Social Policy of Western Europe, Indiana University, Bloomington, online: http://www.iub.edu/ econdept/conference/boeripaper.pdf, [last access on July 26, 2009].

Bremmer, D. and R. Kesselring (2004). Divorce and female labor force participation: Evidence from time-series data and cointegration; Atlantic Economic Journal (32) 3, pp. 175190.

Brunello, G. and S. Comi (2004). Education and Earnings growth: Evidence from 11 European countries; Economics of Education Review 23 (1), pp. 75-83.

Clearinghouse (2009). Comparative Policies, Clearing House on International Developments in Child Youth and Family Policies; online: http://www.childpolicyintl.org/, [last access on July 6, 2009]. 
Del Boca, D., S. Pasqua and C. Pronzato (2005). Fertility and Employment in Italy, France and the UK; Labour 19 (Special Issue), pp. 51-57.

Eckstein, Z, P. Mira and K.I. Wolpin (1998). A quantitative analysis of Swedish fertility dynamics: 1751-1990; CEPR Discussion Paper no. 1832.

eironline (2004). Pension reform finally a reality; online:

http://www.eurofound.europa.eu/eiro/2004/04/feature/sk0404102f.htm, [last access on July 5, 2009].

Elhorst, J.P and m. Tanveer (2008). Female labor force participation behavior and the demographic transition; University of Groningen, Netherlands, online: http://espe.conferenceservices.net/resources/321/1533/pdf/ESPE2009_0167_paper.pdf, [last access on July 20, 2009].

Elhorst, J.P. and A.S. Zeilstra (2007). Labour force participation rates at the regional and national levels of the European Union: An integrated analysis; Papers in Regional Science 86 (4), pp. 525-549.

European Commission (2002). Increasing labour force participation and promoting active aging; online: http://eur-lex.europa.eu/LexUriServ/site/en/com/2002/com2002_0009en01.pdf, [last access on July 25, 2009].

European Council (2000). Presidency Conclusion - Lisbon European Council - 23 and 24 March 2000; online:

http://www.consilium.europa.eu/uedocs/cms_data/docs/pressdata/en/ec/00100-r1.en0.htm, [last access on July 7, 2009].

European Parliament (2009). Attitudes and opinions of women in Europe prior to the 2009 elections - Summary analysis; online:

http://ec.europa.eu/public_opinion/archives/ebs/ebs_pe_women_sum_en.pdf, [last access on July 6, 2009].

Eurostat (2009). Online Database; online: http://epp.eurostat.ec.europa.eu/portal/page/portal/statistics/themes, [last access on July 26, 2009]. 
Eurostat - Labor Force Survey (2009a). Online Database; online:

http://epp.eurostat.ec.europa.eu/portal/page/portal/employment_unemployment_lfs/data/datab ase, [last access on July 26, 2009].

Eurostat - Labor Force Survey (2009b). LFS series - Detailed quarterly survey results (from 1998), Reference Metadata in Euro SDMX Metadata Structure (ESMS); online: http://epp.eurostat.ec.europa.eu/cache/ITY_SDDS/EN/lfsq_esms.htm, [last access on 27 July 2009].

Eurostat (2008). ESSPROS Manual - The European System of integrated Social PROtection Statistics (ESSPROS); Eurostat Methodologies and Working Papers, online: http://circa.europa.eu/Public/irc/dsis/esspros/library?1=/4_publications/esspros_manual_1996/ ks-ra-07-027-en/_EN_1.0_\&a=d [last access: July 22, 2009].

Euwals, R., M. Knoef and D.J. van Vuuren (2007). The trend in female labor force participation: What can be expected for the future?; IZA Discussion Paper no. 3225.

Fallick, B. and J. Pingle (2007). A cohort based model of labor force participation; FEDS Working Paper no. 2007-09.

Gauthier, A.H. and A. Bortnik (2001). Comparative Maternity, Parental, and Childcare

Database, Version 2 (University of Calgary); online:

http://soci.ucalgary.ca/FYPP/index.php?option=com_content\&task=view\&id=10\&Itemid=9, [last access on July 6, 2009].

Generations and Gender Contextual Database (2006). The Contextual Database of the Generations and Gender Program; online:

http://www.demogr.mpg.de/cgi-bin/databases/cdb/cdb.php, [last access on July 6, 2009].

Genre, V., R.G. Salvador and A. Lamo (2005). European Women - why (don't) they work?; European Central Bank Working Paper no. 454.

Goldin, C. (2006). The quiet revolution that transformed women's employment, education, and family"; NBER Working Paper no. 11953.

Goldin, C. (1994). The U-shaped female labor force function in economic development and economic history; NBER Working Paper no. 4707. 
Gørgens, T. (2002). Reservation wages and working hours for recently unemployed US women; Labor Economics 9 (1), pp. 93-123.

Gros, D. and F. Roth (2008). The post-2010 Lisbon process: The key role of education in employment and competitiveness; CEPS Working Document no. 308.

Gujarati, D.N. (2003). Basic Econometrics; McGraw-Hill Higher Education: New York.

Heckman J.J. and M.R. Killingsworth (1986). Female labor supply: a survey; in: Ashenfelter, O. and D. Card (eds.), Handbook of Labor Economics, Vol. I, pp. 103-204.

IFO-DICE (2009). Ifo's Database for Institutional Comparisons in Europe (DICE); online: http://www.cesifo-group.de/portal/page/portal/ifoHome/a-winfo/d3iiv, [last access on July 6, 2009].

IGME (2009). Child Mortality Estimates; Inter-agency Group on Child Mortality Estimation, online: http://www.childmortality.org/, [last access on July 6, 2009].

ILO-LABORSTA (2009). Database of labor statistics; International Labor Organization, online: http://laborsta.ilo.org/, [last access on July 6, 2009].

ILO-NATLEX (2009). Database of national labour, social security and related human rights legislation; online: http://www.ilo.org/dyn/natlex/natlex_browse.home?p_lang=en, [last access on July 6, 2009].

IMF-World Economic and Financial Surveys (2009). World Economic Outlook Database, International Monetary Fund; online:

http://www.imf.org/external/pubs/ft/weo/2009/01/weodata/index.aspx, [last access on July 6, 2009].

Jaumotte, F. (2003). Labor force participation of women: empirical evidence on the role of policy and other determinants in OECD countries"; OECD Economic Department Working Paper no. 376.

Jordahl, H., P. Poutvaara and J. Tuomala (2008). Comment on Education Returns of Wage Earners and Self-Employed Workers; IFN Working Paper no. 762, online: http://papers.ssrn.com/sol3/papers.cfm?abstract_id=1262828 [last access on 15 July 2009]. 
Luci, A. (2009). The impact of macroeconomic growth on women's labour market participation: Does panel data confirm the "feminisation U" hypothesis?; Discussion Paper, Institut National d'Etudes Démographiques, Paris, online: http://espe.conferenceservices.net/resources/321/1533/pdf/ESPE2009_0221_paper.pdf, [last access on 27 July 2009].

Interparliamentary Union (2009). Information in National Parliaments; online: http://www.ipu.org/english/home.htm, [last access on July 6, 2009].

Interparliamentary Union (2006). Women in politics: 60 Years in retrospect; online: http://www.ipu.org/PDF/publications/wmninfokit06_en.pdf, [last access on July 6, 2009].

Kalemli-Ozcan, S. (2008). The uncertain lifetime and the timing of human capital investment; Journal of Population Economics 21 (3), pp. 557-572.

MISSOC (2009). Comparative Tables on Social Protection, Social Protection Systems in Member States - MISSOC; online:

http://ec.europa.eu/employment_social/missoc/db/public/compareTables.do?lang=en, [last access on July 6, 2009].

OECD (2005). Pensions at a glance - Public Policies across OECD countries; Organization for Economic Co-operation and Development (OECD), Paris.

Social Security online (2009). Social Security Programs Throughout the World; online: http://www.ssa.gov/policy/docs/progdesc/ssptw/, [last access on July 6, 2009].

Staiger, D. and J. Stock (1997). Instrumental Variables Regression with Weak Instruments; Econometrica 65 (3), pp. 557-586.

The Equal Authority (2009). Maternity Leave Information; online: http://www.equality.ie/index.asp?locID=19\&docID=-1, [last access on July 6, 2009].

UN-data (2009). United Nations online database; online: http://data.un.org/Default.aspx, [last access on July 6, 2009].

UN-Population Division (2005). World population prospects: The 2004 revision. 
UNECE (1995). Maternity leave and other types of leave in transition countries and the international definitions of employment and unemployment; United Nations - Economic and Social Council, online: http://www.unece.org/stats/documents/ces/1995/r.20.e.html\#2, [last access on July 6, 2009].

UNESCO (1997). International Standard Classification of Education - ISCED 1997; online: http://www.unescobkk.org/fileadmin/user_upload/aims/ISCED_A.pdf, [last access on July 30, 2009].

UNFPA (2009). State of the World Population 2008; United Nations Population Fund, online: http://www.unfpa.org/swp/2008/presskit/docs/en-swop08-report.pdf, [last access on July 6, 2009].

Van Ewijk, C., N. Draper, H. ter Rele and E. Westerhout (2006). Aging and the sustainability of Dutch public finances; CPB Special Publication no. 61, Netherlands Bureau for Economic Policy Analysis.

Vlasblom, J.D. and J.J. Schippers (2004). Increases in female labor force participation in Europe: similarities and differences; Tjalling C. Koopmans Research Institute, Discussion Paper Series no. 04-12.

Vlasblom, J.D. and J.J. Schippers (2003). The dynamics of female employment around childbirth; Tjalling C. Koopmans Research Institute, Discussion Paper Series no. 03-10.

Wooldridge, J.M. (2002). Econometric analysis of cross section and panel data, MIT Press.

World Bank-Gender Stats (2009). Gender Statistics online database; online: http://web.worldbank.org/WBSITE/EXTERNAL/TOPICS/EXTGENDER/EXTANATOOLS/ EXTSTATINDDATA/EXTGENDERSTATS/0,,menuPK:3237391 pagePK:64168427 piPK: 64168435 theSitePK:3237336,00.html, [last access on July 6, 2009]. 


\section{List of Tables}

Table 1: Educational attainment rates of women aged 25-29 in 2008 .................................. 12

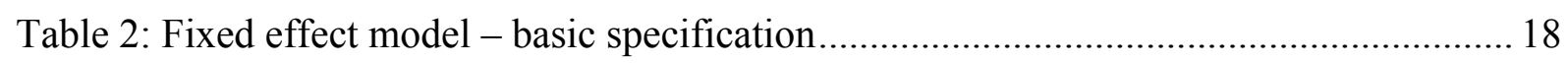

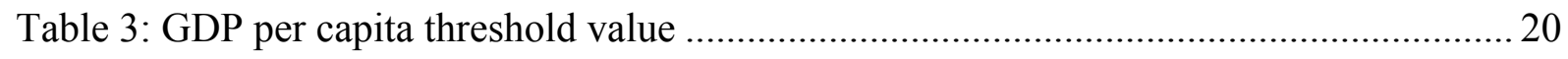

Table 4: Fixed effect model - inclusion of total fertility rate as an explanatory variable ....... 22

Table 5: Fixed effect model - re-estimation for the age-groups 45-49, 50-54, 55-59 and 60-64

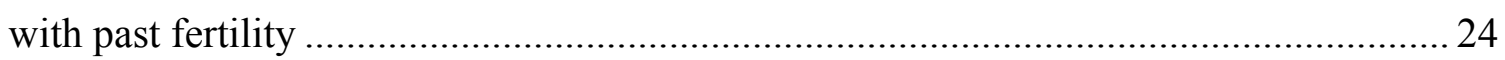

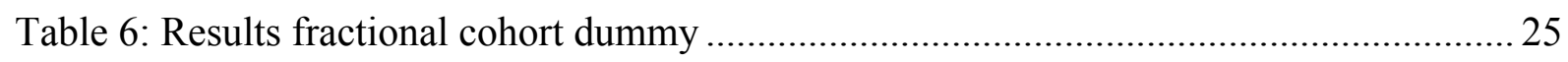

Table 7: Predicted increase of participation rates between 2008 and 2050 ............................ 30

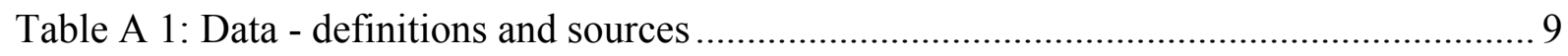

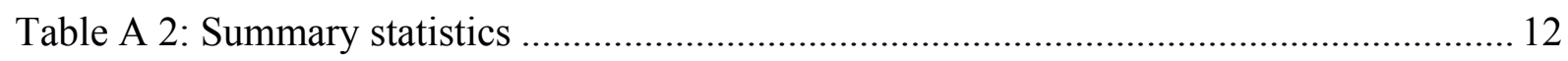

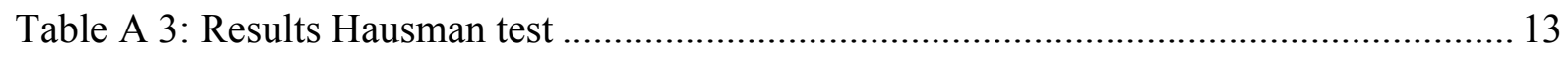

Table A 4: Fixed effect model - including cohort dummy cut off year 1965 ......................... 14

Table A 5: Fixed effect model - including cohort dummy cut off year 1970 ......................... 15

Table A 6: Fixed effect model - including the duration of paid maternal leave and public

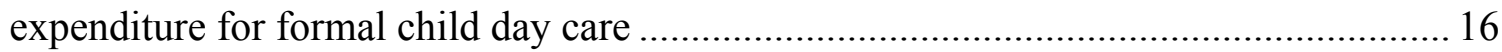

Table A 7: Fixed effect model - including public expenditure for old age benefits................ 17

Table A 8: Educational attainment level in 2008 ............................................................... 18

\section{List of Figures}

Figure 1: Female labor force participation by country and age-group in 2008. 2

Figure 2: Female labor force participation by country, age and educational attainment level in 2008

Figure 3: Female labor force participation by age and country in 1995 and 2008

Figure 4: Difference of highest education level attained of female population (age-groups 25-

29) between 1995 and 2008 


\section{Annex A}

Table A 1: Data - definitions and sources

\begin{tabular}{|c|c|c|}
\hline Variable & Definition & Source \\
\hline $\begin{array}{l}\text { Age-group specific female labor } \\
\text { force participation rate }\end{array}$ & $\begin{array}{l}\text { The ratio of economically active } \\
\text { women in a given age-group to } \\
\text { the female population of the same } \\
\text { age-group. }\end{array}$ & $\begin{array}{l}\text { - Eurostat-Labor Force Survey } \\
(2009 a) \\
\text { In the study data for eight age- } \\
\text { groups are used: } 25-29,30-34 \text {, } \\
35-39,40-44,45-49,50-54,55- \\
59,60-64 \text {. }\end{array}$ \\
\hline $\begin{array}{l}\text { Age-group specific female } \\
\text { educational attainment rate: } \\
\text { - Primary/lower secondary } \\
\text { education } \\
\text { - Upper secondary education } \\
\text { - Tertiary education }\end{array}$ & $\begin{array}{l}\text { The ratio of women in a given } \\
\text { age-group with a certain highest } \\
\text { educational attainment level to } \\
\text { the female population of the same } \\
\text { age-group. } \\
\text { The levels of educational } \\
\text { attainment accord with the } \\
\text { International Standard } \\
\text { Classification of Education } 1997 \\
\text { (ISCED 1997) of UNESCO. } \\
\text { Primary/lower secondary } \\
\text { education refers to ISCED level } \\
\text { 0-2, upper secondary education } \\
\text { refers to ISCED level } 3 \text { and } 4 \text {, } \\
\text { tertiary education refers to } \\
\text { ISCED levels } 5 \text { and } 6 \text {. }\end{array}$ & $\begin{array}{l}\text { Education data: } \\
\text { - Eurostat-Labor Force Survey } \\
\text { (2009a) } \\
\text { Population data: } \\
\text { - Eurostat-Labor Force Survey } \\
\text { (2009a) } \\
\text { - ILO-LABORSTA (2009) for } \\
\text { the year 2008 } \\
\text { In the study data for eight age- } \\
\text { groups are used: } 25-29,30-34, \\
\text { 35-39, } 40-44,45-49,50-54,55- \\
\text { 59, } 60-64 \\
\text { For Germany, Ireland, } \\
\text { Luxembourg and United } \\
\text { Kingdom, data for } 1998 \text { are } \\
\text { linearly interpolated. } \\
\text { For Latvia, the values for the } \\
\text { primary/lower secondary } \\
\text { educational attainment of the } \\
\text { age-group 35-39 in the years } \\
\text { 2005 and 2006, of the age-group } \\
\text { 40-44 in 2006 and of the age- } \\
\text { group } 45-49 \text { in } 2007 \text { are linearly } \\
\text { interpolated. } \\
\text { For Portugal, the values of the } \\
\text { tertiary educational attainment } \\
\text { rate of the age-groups 55-59 and } \\
60-64 \text { in the years } 1998-2000 \text { are } \\
\text { linearly interpolated. }\end{array}$ \\
\hline Total female unemployment rate & $\begin{array}{l}\text { The proportion of unemployment } \\
\text { women (aged } 15 \text { to max) in the } \\
\text { female labor force (aged } 15 \text { to } \\
\text { max). }\end{array}$ & $\begin{array}{l}\text { - Eurostat-Labor Force Survey } \\
(2009 a)\end{array}$ \\
\hline $\begin{array}{l}\text { Total female part-time } \\
\text { employment }\end{array}$ & $\begin{array}{l}\text { The share of part-time employed } \\
\text { women (aged } 15 \text { to max) in total } \\
\text { female employment (aged } 15 \text { to } \\
\text { max). }\end{array}$ & $\begin{array}{l}\text { - Eurostat- Labor Force Survey } \\
(2009 \mathrm{a}) \\
\text { For Ireland the value for the year } \\
2006 \text { is linearly interpolated. }\end{array}$ \\
\hline $\begin{array}{l}\text { Logarithm of GDP per capita and } \\
\text { squared logarithm of GDP per } \\
\text { capita }\end{array}$ & $\begin{array}{l}\text { Purchasing Power Parity GDP } \\
\text { per capita in current international } \\
\text { US\$. }\end{array}$ & $\begin{array}{l}\text { - IMF-World Economic and } \\
\text { Financial Surveys (2009) }\end{array}$ \\
\hline Crude marriage rate & $\begin{array}{l}\text { Number of marriages in one year } \\
\text { to the average population in that }\end{array}$ & $\begin{array}{l}\text { - Eurostat (2009) } \\
\text { Values for the year } 2008 \text { are }\end{array}$ \\
\hline
\end{tabular}




\begin{tabular}{|c|c|c|}
\hline & $\begin{array}{l}\text { year (expressed per } 1000 \\
\text { inhabitants). }\end{array}$ & linearly extrapolated. \\
\hline Crude divorce rate & $\begin{array}{l}\text { Number of divorces in one year } \\
\text { to the average population in that } \\
\text { year (expressed per } 1000 \\
\text { inhabitants). }\end{array}$ & $\begin{array}{l}\text { - Eurostat (2009) } \\
\text { Values for the year } 2008 \text { are } \\
\text { linearly extrapolated. }\end{array}$ \\
\hline Total fertility rate & $\begin{array}{l}\text { Average number of children that } \\
\text { would be born to a woman over } \\
\text { her fertile life. }\end{array}$ & $\begin{array}{l}\text { - World Bank-Gender-Stats } \\
\text { (2009) } \\
\text { - UNFPA (2009) } \\
\text { - UN-Population Division (2005) } \\
\text { For Cyprus and Luxembourg, } \\
\text { missing values for the year } 2008 \\
\text { are replaced by the } 2007 \text { value. }\end{array}$ \\
\hline Duration paid maternal leave & $\begin{array}{l}\text { Maternal leave is the time off } \\
\text { work granted to a mother because } \\
\text { of pregnancy and childbirth. The } \\
\text { data include parental leave } \\
\text { opportunities for mothers but } \\
\text { exclude unpaid leave. }\end{array}$ & $\begin{array}{l}\text { - World Bank-Gender Stats } \\
\text { (2009) } \\
\text { - Gauthier and Bortnik (2001) } \\
\text { - ILO-NATLEX (2009) } \\
\text { - Clearing House (2009) } \\
\text { - UN-data (2009) } \\
\text { - UNECE (1995) } \\
\text { - Generations and Gender } \\
\text { Contextual Database (2006) } \\
\text { - Social Security Online (2009) } \\
\text { - The Equality Authority (2009) } \\
\text { - IFO-DICE (2009) } \\
\text { - MISSOC (2009) } \\
\text { The duration of paid maternal } \\
\text { leave refers to the maximum } \\
\text { leave period (including parental } \\
\text { leave) before and after the birth } \\
\text { of the first child. } \\
\text { For missing years where data are } \\
\text { available before and after, it is } \\
\text { expected that maternal leave } \\
\text { duration does not change within } \\
\text { that period. } \\
\text { If no data are available for the } \\
\text { starting year, the next closest } \\
\text { value is taken. }\end{array}$ \\
\hline $\begin{array}{l}\text { Public expenditure for old age } \\
\text { benefits (non-means tested) }\end{array}$ & $\begin{array}{l}\text { Regular payments to maintain } \\
\text { income from employment after } \\
\text { retirement or to support income } \\
\text { of elderly. }\end{array}$ & $\begin{array}{l}\text { Eurostat (2009) } \\
\text { - For definitions of social } \\
\text { protection data see Eurostat } \\
(2008) .\end{array}$ \\
\hline $\begin{array}{l}\text { Public expenditure for child day } \\
\text { care (non-means tested) }\end{array}$ & $\begin{array}{l}\text { Child day care including shelter } \\
\text { and board that are provided to } \\
\text { pre-school children. }\end{array}$ & $\begin{array}{l}\text { Eurostat (2009) } \\
\text { - For definitions of social } \\
\text { protection data see Eurostat } \\
(2008) \text {. }\end{array}$ \\
\hline Women parliamentary Seats & $\begin{array}{l}\text { The share of seats in national } \\
\text { parliaments held by women. }\end{array}$ & $\begin{array}{l}\text { - World Bank-Gender Stats } \\
\text { (2009) } \\
\text { - UN-data (2009) } \\
\text { - Inter Parliamentary Union } \\
(2009,2006)\end{array}$ \\
\hline
\end{tabular}




\begin{tabular}{|l|l|l|}
\hline Unadjusted gender paygap & $\begin{array}{l}\text { Difference between average gross } \\
\text { hourly earnings of men and } \\
\text { women. }\end{array}$ & $\begin{array}{l}\text { - Eurostat (2009) } \\
\text { - European Parliament (2009) }\end{array}$ \\
\hline Instrument for total fertility rate: & $\begin{array}{l}\text { The probability that a child will } \\
\text { die before reaching the age of } \\
\text { five (expressed per 1000 } \\
\text { children). }\end{array}$ & $\begin{array}{l}\text { - World Bank (2009) } \\
\text { - IGME (2009) } \\
\text { Values for the year 2008 are } \\
\text { linearly extrapolated. }\end{array}$ \\
\hline Child mortality under 5 rate & $\begin{array}{l}\text { Number of women in 5year age- } \\
\text { groups (in thousands) in 2050 }\end{array}$ & UN-Population Division (2005) \\
\hline Population forecast for 2050 & cf. Total fertility rate & UN-Population Division (2005) \\
\hline $\begin{array}{l}\text { Total fertility rate forecast for } \\
2050\end{array}$ & & \\
\hline
\end{tabular}


Table A 2: Summary statistics

\begin{tabular}{|c|c|c|c|c|c|}
\hline Variable & \# Obs. & Mean & SD & Min & Max \\
\hline \multicolumn{6}{|c|}{ Female labor force participation rate: } \\
\hline Participation rate: age $25-29$ & 322 & 0.762 & 0.070 & 0.520 & 0.913 \\
\hline Participation rate: age $30-34$ & 322 & 0.773 & 0.073 & 0.561 & 0.954 \\
\hline Participation rate: age 35-39 & 322 & 0.785 & 0.087 & 0.523 & 0.971 \\
\hline Participation rate: age $40-44$ & 322 & 0.787 & 0.102 & 0.480 & 0.928 \\
\hline Participation rate: age $45-49$ & 322 & 0.752 & 0.121 & 0.432 & 0.925 \\
\hline Participation rate: age 50-54 & 322 & 0.655 & 0.145 & 0.313 & 0.885 \\
\hline Participation rate: age 55-59 & 322 & 0.427 & 0.172 & 0.141 & 0.806 \\
\hline Participation rate: age $60-64$ & 322 & 0.193 & 0.119 & 0.027 & 0.590 \\
\hline \multicolumn{6}{|c|}{ Female educational attainment rate: } \\
\hline \multicolumn{6}{|c|}{ Primary/lower secondary education: } \\
\hline Age-group 25-29 & 301 & 0.193 & 0.118 & 0.038 & 0.639 \\
\hline Age-group 30-34 & 301 & 0.224 & 0.143 & 0.036 & 0.735 \\
\hline Age-group 35-39 & 301 & 0.263 & 0.162 & 0.041 & 0.772 \\
\hline Age-group 40-44 & 301 & 0.311 & 0.178 & 0.034 & 0.879 \\
\hline Age-group 45-49 & 301 & 0.371 & 0.190 & 0.049 & 0.954 \\
\hline Age-group 50-54 & 301 & 0.433 & 0.194 & 0.067 & 1.006 \\
\hline Age-group 55-59 & 301 & 0.508 & 0.199 & 0.140 & 1.014 \\
\hline Age-group 60-64 & $287^{*}$ & 0.590 & 0.190 & 0.216 & 0.998 \\
\hline \multicolumn{6}{|l|}{ Upper secondary education: } \\
\hline Age-group 25-29 & 301 & 0.506 & 0.152 & 0.197 & 0.828 \\
\hline Age-group 30-34 & 301 & 0.494 & 0.167 & 0.135 & 0.931 \\
\hline Age-group 35-39 & 301 & 0.490 & 0.169 & 0.110 & 0.829 \\
\hline Age-group 40-44 & 301 & 0.467 & 0.172 & 0.074 & 0.811 \\
\hline Age-group 45-49 & 301 & 0.432 & 0.172 & 0.057 & 0.756 \\
\hline Age-group 50-54 & 301 & 0.390 & 0.172 & 0.042 & 0.727 \\
\hline Age-group 55-59 & 301 & 0.343 & 0.169 & 0.030 & 0.724 \\
\hline Age-group 60-64 & $287^{*}$ & 0.296 & 0.157 & 0.017 & 0.722 \\
\hline \multicolumn{6}{|l|}{ Tertiary education: } \\
\hline Age-group 25-29 & 301 & 0.284 & 0.117 & 0.074 & 0.572 \\
\hline Age-group 30-34 & 301 & 0.267 & 0.114 & 0.083 & 0.588 \\
\hline Age-group 35-39 & 301 & 0.235 & 0.097 & 0.072 & 0.521 \\
\hline Age-group 40-44 & 301 & 0.211 & 0.088 & 0.080 & 0.516 \\
\hline Age-group 45-49 & 301 & 0.190 & 0.082 & 0.047 & 0.441 \\
\hline Age-group 50-54 & 301 & 0.165 & 0.076 & 0.042 & 0.394 \\
\hline Age-group 55-59 & 301 & 0.132 & 0.065 & 0.024 & 0.327 \\
\hline Age-group 60-64 & $287^{*}$ & 0.098 & 0.056 & 0.020 & 0.282 \\
\hline
\end{tabular}

${ }^{*}$ Data for United Kingdom are left out because of inconsistencies. 
Table A 3: Results Hausman test

Test: Null Hypothesis: difference in coefficients not systematic

\begin{tabular}{|c|c|c|c|c|c|c|c|c|}
\hline \multirow[b]{2}{*}{ Variable } & \multicolumn{2}{|c|}{ Age-group 25-29 } & \multicolumn{2}{|c|}{ Age-group 30-34 } & \multicolumn{2}{|c|}{ Age-group 35-39 } & \multicolumn{2}{|c|}{ Age-group 40-44 } \\
\hline & Consistent & Efficient & Consistent & Efficient & Consistent & Efficient & Consistent & Efficient \\
\hline Total fertility rate & -0.651 & -0.183 & -4.520 & -0.241 & -4.152 & -0.178 & 0.222 & -0.103 \\
\hline $\begin{array}{l}\text { Upper secondary } \\
\text { education }\end{array}$ & 0.446 & 0.421 & 0.750 & 0.723 & 1.711 & 1.214 & 0.594 & 0.620 \\
\hline Tertiary education & 0.346 & 0.439 & 0.606 & 0.778 & 0.668 & 1.163 & 0.920 & 0.915 \\
\hline $\begin{array}{c}\text { Total female } \\
\text { unemployment rate }\end{array}$ & -0.609 & -0.107 & -4.558 & 0.101 & -4.035 & 0.460 & 0.070 & -0.285 \\
\hline $\begin{array}{c}\text { Share total female } \\
\text { part-time } \\
\text { employment }\end{array}$ & 0.150 & 0.161 & 0.909 & 0.869 & 1.349 & 1.411 & 2.301 & 2.305 \\
\hline $\begin{array}{l}\text { Share women in } \\
\text { parliament }\end{array}$ & 0.147 & 0.043 & 1.711 & 0.854 & 1.626 & 0.792 & 0.320 & 0.382 \\
\hline $\begin{array}{c}\text { Logarithm of GDP } \\
\text { per capita }\end{array}$ & -3.632 & -3.306 & -9.355 & -6.298 & -6.876 & -3.817 & -1.995 & -2.199 \\
\hline $\begin{array}{l}\text { Squared logarithm } \\
\text { of GDP per capita }\end{array}$ & 0.197 & 0.178 & 0.488 & 0.321 & 0.357 & 0.189 & 0.104 & 0.115 \\
\hline $\begin{array}{l}\text { Lagged crude } \\
\text { marriage rate }\end{array}$ & 0.057 & -0.367 & 4.089 & 0.063 & 2.788 & -1.117 & -2.945 & -2.609 \\
\hline $\begin{array}{l}\text { Lagged crude } \\
\text { divorce rate }\end{array}$ & 2.246 & 4.692 & -8.902 & 13.260 & -6.725 & 14.427 & 9.066 & 7.372 \\
\hline Constant & 18.359 & 16.238 & 51.889 & 31.206 & 39.252 & 19.204 & 9.420 & 10.866 \\
\hline Chi2 & & & 12.6 & 10 & 8.9 & & & \\
\hline Prob>chi2 & 1. & & 0.2 & & 0.53 & 44 & 1.0 & 00 \\
\hline
\end{tabular}

\begin{tabular}{|c|c|c|c|c|c|c|c|c|}
\hline \multirow[b]{2}{*}{ Variable } & \multicolumn{2}{|c|}{ Age-group 45-49 } & \multicolumn{2}{|c|}{ Age-group 50-54 } & \multicolumn{2}{|c|}{ Age-group 55-59 } & \multicolumn{2}{|c|}{ Age-group 60-64 } \\
\hline & Consistent & Efficient & Consistent & Efficient & Consistent & Efficient & Consistent & Efficient \\
\hline Total fertility rate & -2.377 & 0.155 & -0.071 & 0.013 & 3.212 & 0.415 & 4.165 & 0.555 \\
\hline $\begin{array}{l}\text { Upper secondary } \\
\text { education }\end{array}$ & -0.085 & 0.118 & -0.233 & -0.230 & -0.100 & -0.549 & 0.116 & -0.318 \\
\hline Tertiary education & 0.122 & 0.856 & 1.553 & 1.543 & 1.209 & 1.932 & 4.687 & 6.233 \\
\hline $\begin{array}{c}\text { Total female } \\
\text { unemployment rate }\end{array}$ & -3.027 & -0.105 & -0.530 & -0.442 & 3.063 & 0.230 & 3.422 & -0.493 \\
\hline $\begin{array}{l}\text { Share total female } \\
\text { part-time } \\
\text { employment }\end{array}$ & 2.286 & 2.292 & 2.445 & 2.442 & 2.181 & 2.336 & 1.732 & 2.353 \\
\hline $\begin{array}{l}\text { Share women in } \\
\text { parliament }\end{array}$ & 1.119 & 0.558 & 0.114 & 0.099 & -1.219 & -0.791 & -0.938 & -0.411 \\
\hline $\begin{array}{c}\text { Logarithm of GDP } \\
\text { per capita }\end{array}$ & -5.791 & -3.611 & -2.484 & -2.442 & 0.252 & -0.525 & 0.073 & -0.264 \\
\hline $\begin{array}{l}\text { Squared logarithm } \\
\text { of GDP per capita }\end{array}$ & 0.321 & 0.199 & 0.152 & 0.150 & 0.027 & 0.074 & -0.012 & 0.007 \\
\hline $\begin{array}{l}\text { Lagged crude } \\
\text { marriage rate }\end{array}$ & 0.506 & -1.705 & -3.303 & -3.384 & -3.347 & -0.684 & -0.390 & 2.993 \\
\hline $\begin{array}{l}\text { Lagged crude } \\
\text { divorce rate }\end{array}$ & 2.063 & 15.362 & 16.328 & 16.749 & 21.582 & 8.221 & 23.087 & 8.031 \\
\hline Constant & 29.960 & 16.075 & 9.512 & 9.191 & -11.252 & -3.735 & -8.741 & -1.727 \\
\hline Chi2 & \multicolumn{2}{|c|}{3.28} & \multicolumn{2}{|c|}{0.01} & \multicolumn{2}{|c|}{3.27} & \multicolumn{2}{|c|}{5.39} \\
\hline Prob $>$ chi2 & \multicolumn{2}{|c|}{0.9740} & \multicolumn{2}{|c|}{1.0000} & \multicolumn{2}{|c|}{0.9742} & \multicolumn{2}{|c|}{0.8638} \\
\hline
\end{tabular}

The regressions are estimated using OLS. Each regression includes fixed effects. 
Table A 4: Fixed effect model - including cohort dummy cut off year 1965

Dependent variable: Female labor market participation rate

\begin{tabular}{|c|c|c|c|}
\hline Age-group & 30-34 & 35-39 & $40-44$ \\
\hline Upper secondary education & $\begin{array}{l}0.636 * * * \\
(0.137)\end{array}$ & $\begin{array}{l}0.996^{* * *} \\
(0.183)\end{array}$ & $\begin{array}{l}0.616^{* * *} \\
(0.163)\end{array}$ \\
\hline Tertiary education & $\begin{array}{l}0.642 * * * \\
(0.200)\end{array}$ & $\begin{array}{l}1.004 * * * \\
(0.237)\end{array}$ & $\begin{array}{l}0.840 * * * \\
(0.213)\end{array}$ \\
\hline Total female unemployment rate & $\begin{array}{l}0.681 * * * \\
(0.240)\end{array}$ & $\begin{array}{l}0.366 \\
(0.250)\end{array}$ & $\begin{array}{l}-0.155 \\
(0.221)\end{array}$ \\
\hline $\begin{array}{l}\text { Share of total female } \\
\text { part-time employment }\end{array}$ & $\begin{array}{l}0.950 * * * \\
(0.192)\end{array}$ & $\begin{array}{l}1.382 * * * \\
(0.193)\end{array}$ & $\begin{array}{l}2.128 * * * \\
(0.174)\end{array}$ \\
\hline Share of women in parliament & $\begin{array}{l}0.594 * * * \\
(0.179)\end{array}$ & $\begin{array}{l}0.512 * * * \\
(0.177)\end{array}$ & $\begin{array}{l}0.354 * * \\
(0.153)\end{array}$ \\
\hline Logarithm of GDP per capita & $\begin{array}{l}-5.296 * * * \\
(0.712)\end{array}$ & $\begin{array}{l}-4.792 * * * \\
(0.695)\end{array}$ & $\begin{array}{l}-2.792 * * * \\
(0.738)\end{array}$ \\
\hline $\begin{array}{l}\text { Squared logarithm of } \\
\text { GDP per capita }\end{array}$ & $\begin{array}{l}0.269 * * * \\
(0.037)\end{array}$ & $\begin{array}{l}0.244 * * * \\
(0.036)\end{array}$ & $\begin{array}{l}0.146^{* * * *} \\
(0.038)\end{array}$ \\
\hline Lagged marriage rate & $\begin{array}{l}0.232 \\
(0.907)\end{array}$ & $\begin{array}{l}-2.551 * * * \\
(0.761)\end{array}$ & $\begin{array}{l}-2.781 * * * \\
(0.589)\end{array}$ \\
\hline Lagged divorce rate & $\begin{array}{l}15.395 * * * \\
(2.295)\end{array}$ & $\begin{array}{l}14.209 * * * \\
(2.219)\end{array}$ & $\begin{array}{l}10.125^{* * * *} \\
(2.016)\end{array}$ \\
\hline Total fertility rate & $\begin{array}{l}-0.209 * * \\
(0.087)\end{array}$ & $\begin{array}{l}-0.083 \\
(0.093)\end{array}$ & $\begin{array}{l}-0.124^{*} \\
(0.075)\end{array}$ \\
\hline $\begin{array}{l}\text { Cohort dummy } \\
\text { cut-off year } 1965\end{array}$ & $\begin{array}{l}0.109 * * * \\
(0.026)\end{array}$ & & \\
\hline $\begin{array}{l}\text { Cohort dummy } \\
\text { cut-off year } 1965\end{array}$ & & $\begin{array}{l}-0.034 \\
(0.029)\end{array}$ & \\
\hline $\begin{array}{l}\text { Cohort dummy } \\
\text { cut-off year } 1965\end{array}$ & & & $\begin{array}{l}0.007 \\
(0.031)\end{array}$ \\
\hline Constant & $\begin{array}{l}25.829 * * * \\
(3.492)\end{array}$ & $\begin{array}{l}22.732 * * * \\
(3.447)\end{array}$ & $\begin{array}{l}12.725^{* * * *} \\
(3.589)\end{array}$ \\
\hline $\begin{array}{l}\text { Observations } \\
\text { Number of countries } \\
\text { Wald test: } \text { Prob }>\text { chi2 }\end{array}$ & $\begin{array}{l}301 \\
23 \\
0.0000\end{array}$ & $\begin{array}{l}301 \\
23 \\
0.0000\end{array}$ & $\begin{array}{l}301 \\
23 \\
0.0000\end{array}$ \\
\hline
\end{tabular}

Standard errors in parentheses

* significant at $10 \%$; ** significant at 5\%; *** significant at $1 \%$

The regressions are estimated using FGLS. Each regression includes country dummies. 
Table A 5: Fixed effect model - including cohort dummy cut off year 1970

Dependent variable: Female labor market participation rate

\begin{tabular}{|c|c|c|c|}
\hline Age-group & 25-29 & $30-34$ & 35-39 \\
\hline Upper secondary education & $\begin{array}{l}0.365 * * * \\
(0.116)\end{array}$ & $\begin{array}{l}0.728 * * * \\
(0.138)\end{array}$ & $\begin{array}{l}1.016^{* * *} \\
(0.182)\end{array}$ \\
\hline Tertiary education & $\begin{array}{l}0.393 * * \\
(0.180)\end{array}$ & $\begin{array}{l}0.661 * * * \\
(0.221)\end{array}$ & $\begin{array}{l}0.910 * * * \\
(0.226)\end{array}$ \\
\hline Total female unemployment rate & $\begin{array}{l}0.240 \\
(0.260)\end{array}$ & $\begin{array}{l}0.630^{* *} \\
(0.272)\end{array}$ & $\begin{array}{l}0.178 \\
(0.234)\end{array}$ \\
\hline $\begin{array}{l}\text { Share of total female } \\
\text { part-time employment }\end{array}$ & $\begin{array}{l}0.274 \\
(0.188)\end{array}$ & $\begin{array}{l}1.174 * * * \\
(0.207)\end{array}$ & $\begin{array}{l}1.339 * * * \\
(0.189)\end{array}$ \\
\hline Share of women in parliament & $\begin{array}{l}-0.005 \\
(0.184)\end{array}$ & $\begin{array}{l}0.870 * * * \\
(0.186)\end{array}$ & $\begin{array}{l}0.462 * * * \\
(0.170)\end{array}$ \\
\hline Logarithm of GDP per capita & $\begin{array}{l}-3.153 * * * \\
(0.731)\end{array}$ & $\begin{array}{l}-5.186 * * * \\
(0.786)\end{array}$ & $\begin{array}{l}-4.980 * * * \\
(0.705)\end{array}$ \\
\hline $\begin{array}{l}\text { Squared logarithm of } \\
\text { GDP per capita }\end{array}$ & $\begin{array}{l}0.169 * * * \\
(0.037)\end{array}$ & $\begin{array}{l}0.275 * * * \\
(0.040)\end{array}$ & $\begin{array}{l}0.249 * * * \\
(0.037)\end{array}$ \\
\hline Lagged marriage rate & $\begin{array}{l}0.483 \\
(0.659)\end{array}$ & $\begin{array}{l}-0.536 \\
(0.868)\end{array}$ & $\begin{array}{l}-2.156 * * * \\
(0.678)\end{array}$ \\
\hline Lagged divorce rate & $\begin{array}{l}5.412 * * * \\
(2.031)\end{array}$ & $\begin{array}{l}14.429 * * * \\
(2.309)\end{array}$ & $\begin{array}{l}14.338 * * * \\
(2.162)\end{array}$ \\
\hline Total fertility rate & $\begin{array}{l}-0.222 * * * \\
(0.081)\end{array}$ & $\begin{array}{l}-0.191 * * \\
(0.091)\end{array}$ & $\begin{array}{l}-0.127 \\
(0.087)\end{array}$ \\
\hline $\begin{array}{l}\text { Cohort dummy } \\
\text { cut-off year } 1970\end{array}$ & $\begin{array}{l}0.050 * * \\
(0.024)\end{array}$ & & \\
\hline $\begin{array}{l}\text { Cohort dummy } \\
\text { cut-off year } 1970\end{array}$ & & $\begin{array}{l}-0.079 * * * \\
(0.031)\end{array}$ & \\
\hline $\begin{array}{l}\text { Cohort dummy } \\
\text { cut-off year } 1970\end{array}$ & & & $\begin{array}{l}0.069 * * \\
(0.034)\end{array}$ \\
\hline Constant & $\begin{array}{l}15.314 * * * \\
(3.601)\end{array}$ & $\begin{array}{l}23.887 * * * \\
(3.898)\end{array}$ & $\begin{array}{l}24.259 * * * \\
(3.433)\end{array}$ \\
\hline $\begin{array}{l}\text { Observations } \\
\text { Number of countries } \\
\text { Wald test: Prob }>\text { chi2 }\end{array}$ & $\begin{array}{l}301 \\
23 \\
0.0000\end{array}$ & $\begin{array}{l}301 \\
23 \\
0.0000 \\
\end{array}$ & $\begin{array}{l}301 \\
23 \\
0.0000 \\
\end{array}$ \\
\hline
\end{tabular}

Standard errors in parentheses

* significant at $10 \%$; ** significant at 5\%; *** significant at $1 \%$

The regressions are estimated using FGLS. Each regression includes country dummies. 
Table A 6: Fixed effect model - including the duration of paid maternal leave and public expenditure for formal child day care

Dependent variable: Female labor market participation rate

\begin{tabular}{|c|c|c|c|c|c|}
\hline Age-group & $25-29$ & $30-34$ & 35-39 & $40-44$ & 45-49 \\
\hline Upper secondary education & $\begin{array}{l}0.835 * * * \\
(0.131)\end{array}$ & $\begin{array}{l}1.056^{* * *} \\
(0.177)\end{array}$ & $\begin{array}{l}1.201 * * * \\
(0.226)\end{array}$ & $\begin{array}{l}1.075^{* * *} \\
(0.218)\end{array}$ & $\begin{array}{l}0.331 \\
(0.203)\end{array}$ \\
\hline Tertiary education & $\begin{array}{l}0.553 * * \\
(0.221)\end{array}$ & $\begin{array}{l}0.531 * * \\
(0.249)\end{array}$ & $\begin{array}{l}0.841 * * * \\
(0.281)\end{array}$ & $\begin{array}{l}1.088 * * * \\
(0.264)\end{array}$ & $\begin{array}{l}0.660 * * * \\
(0.238)\end{array}$ \\
\hline Total female unemployment rate & $\begin{array}{l}-0.028 \\
(0.287)\end{array}$ & $\begin{array}{l}-0.335 \\
(0.275)\end{array}$ & $\begin{array}{l}0.114 \\
(0.275)\end{array}$ & $\begin{array}{l}-0.276 \\
(0.268)\end{array}$ & $\begin{array}{l}-0.204 \\
(0.279)\end{array}$ \\
\hline $\begin{array}{l}\text { Share of total female } \\
\text { part-time employment }\end{array}$ & $\begin{array}{l}-0.159 \\
(0.192)\end{array}$ & $\begin{array}{l}0.747 * * * \\
(0.209)\end{array}$ & $\begin{array}{l}1.156^{* * *} \\
(0.208)\end{array}$ & $\begin{array}{l}1.985 * * * \\
(0.213)\end{array}$ & $\begin{array}{l}2.437 * * * \\
(0.215)\end{array}$ \\
\hline Share of women in parliament & $\begin{array}{l}-0.070 \\
(0.200)\end{array}$ & $\begin{array}{l}0.267 \\
(0.203)\end{array}$ & $\begin{array}{l}0.238 \\
(0.203)\end{array}$ & $\begin{array}{l}0.078 \\
(0.162)\end{array}$ & $\begin{array}{l}0.521 * * * \\
(0.149)\end{array}$ \\
\hline Logarithm of GDP per capita & $\begin{array}{l}-4.944 * * * \\
(0.878)\end{array}$ & $\begin{array}{l}-6.248 * * * \\
(1.314)\end{array}$ & $\begin{array}{l}-4.422 * * * \\
(0.917)\end{array}$ & $\begin{array}{l}-1.530 \\
(1.035)\end{array}$ & $\begin{array}{l}-0.673 \\
(1.145)\end{array}$ \\
\hline $\begin{array}{l}\text { Squared logarithm of } \\
\text { GDP per capita }\end{array}$ & $\begin{array}{l}0.264 * * * \\
(0.045)\end{array}$ & $\begin{array}{l}0.330 * * * \\
(0.067)\end{array}$ & $\begin{array}{l}0.226 * * * \\
(0.048)\end{array}$ & $\begin{array}{l}0.083 \\
(0.053)\end{array}$ & $\begin{array}{l}0.056 \\
(0.058)\end{array}$ \\
\hline Lagged marriage rate & $\begin{array}{l}1.101 \\
(0.811)\end{array}$ & $\begin{array}{l}1.132 \\
(0.872)\end{array}$ & $\begin{array}{l}-0.914 \\
(0.701)\end{array}$ & $\begin{array}{l}-2.766^{* * *} \\
(0.711)\end{array}$ & $\begin{array}{l}-1.698^{*} \\
(0.884)\end{array}$ \\
\hline Lagged divorce rate & $\begin{array}{l}-4.828 * \\
(2.468)\end{array}$ & $\begin{array}{l}9.264 * * * \\
(3.137)\end{array}$ & $\begin{array}{l}12.834 * * * \\
(3.000)\end{array}$ & $\begin{array}{l}4.230 \\
(2.610)\end{array}$ & $\begin{array}{l}7.771 * * * \\
(2.333)\end{array}$ \\
\hline Total fertility rate & $\begin{array}{l}0.067 \\
(0.095)\end{array}$ & $\begin{array}{l}-0.089 \\
(0.099)\end{array}$ & $\begin{array}{l}-0.047 \\
(0.106)\end{array}$ & $\begin{array}{l}-0.005 \\
(0.096)\end{array}$ & \\
\hline $\begin{array}{l}\text { Total fertility rate } \\
5 \text { years ago }\end{array}$ & & & & & $\begin{array}{l}0.161 \\
(0.108)\end{array}$ \\
\hline Duration paid maternal leave & $\begin{array}{l}0.116 \\
(0.072)\end{array}$ & $\begin{array}{l}0.137^{*} \\
(0.079)\end{array}$ & $\begin{array}{l}0.112 \\
(0.079)\end{array}$ & $\begin{array}{l}0.053 \\
(0.065)\end{array}$ & \\
\hline Duration paid maternal leave square & $\begin{array}{l}-0.003 * \\
(0.002)\end{array}$ & $\begin{array}{l}-0.004 * * \\
(0.002)\end{array}$ & $\begin{array}{l}-0.003 \\
(0.002)\end{array}$ & $\begin{array}{l}-0.002 \\
(0.001)\end{array}$ & \\
\hline $\begin{array}{l}\text { Duration paid leave } \\
5 \text { years ago }\end{array}$ & & & & & $\begin{array}{l}0.206 \\
(0.152)\end{array}$ \\
\hline $\begin{array}{l}\text { Duration paid leave square } \\
5 \text { years ago }\end{array}$ & & & & & $\begin{array}{l}-0.006 \\
(0.005)\end{array}$ \\
\hline $\begin{array}{l}\text { Expenditure child day care } \\
\text { (percent GDP) }\end{array}$ & $\begin{array}{l}0.066 \\
(0.057)\end{array}$ & $\begin{array}{l}0.069 \\
(0.051)\end{array}$ & $\begin{array}{l}0.144 * * * \\
(0.052)\end{array}$ & $\begin{array}{l}-0.021 \\
(0.057)\end{array}$ & $\begin{array}{l}0.192 * * * \\
(0.064)\end{array}$ \\
\hline Constant & $\begin{array}{l}30.534 * * * \\
(5.580)\end{array}$ & $\begin{array}{l}37.142 * * * \\
(7.800)\end{array}$ & $\begin{array}{l}28.107 * * * \\
(5.721)\end{array}$ & $\begin{array}{l}11.188 * \\
(5.897)\end{array}$ & $\begin{array}{l}14.845 \\
(13.289)\end{array}$ \\
\hline Observations & 218 & 218 & 218 & 218 & 218 \\
\hline Number of countries & 20 & 20 & 20 & 20 & 20 \\
\hline Wald test: Prob $>$ chi2 & 0.0000 & 0.0000 & 0.0000 & 0.0000 & 0.0000 \\
\hline
\end{tabular}


Table A 7: Fixed effect model - including public expenditure for old age benefits

Dependent variable : Female labor market participation rate

\begin{tabular}{|c|c|c|c|}
\hline Age-group & $50-54$ & 55-59 & 60-64 \\
\hline Upper secondary education & $\begin{array}{l}0.230 \\
(0.177)\end{array}$ & $\begin{array}{l}-0.576^{* *} \\
(0.238)\end{array}$ & $\begin{array}{l}-0.504 \\
(0.348)\end{array}$ \\
\hline Tertiary education & $\begin{array}{l}0.885 * * * \\
(0.294)\end{array}$ & $\begin{array}{l}2.156^{* * * *} \\
(0.435)\end{array}$ & $\begin{array}{l}2.314 * * * \\
(0.720)\end{array}$ \\
\hline Total female unemployment rate & $\begin{array}{l}0.177 \\
(0.232)\end{array}$ & $\begin{array}{l}0.685 * * * \\
(0.213)\end{array}$ & $\begin{array}{l}-0.919 * * * \\
(0.277)\end{array}$ \\
\hline $\begin{array}{l}\text { Share of total female } \\
\text { part-time employment }\end{array}$ & $\begin{array}{l}1.696^{* * *} \\
(0.219)\end{array}$ & $\begin{array}{l}1.982 * * * \\
(0.230)\end{array}$ & $\begin{array}{l}1.625^{* * *} \\
(0.313)\end{array}$ \\
\hline Share of women in parliament & $\begin{array}{l}0.032 \\
(0.190)\end{array}$ & $\begin{array}{l}-0.019 \\
(0.169)\end{array}$ & $\begin{array}{l}-0.062 \\
(0.247)\end{array}$ \\
\hline Logarithm of GDP per capita & $\begin{array}{l}-1.186 \\
(1.008)\end{array}$ & $\begin{array}{l}0.630 \\
(1.531)\end{array}$ & $\begin{array}{l}2.746 \\
(1.897)\end{array}$ \\
\hline $\begin{array}{l}\text { Squared logarithm of } \\
\text { GDP per capita }\end{array}$ & $\begin{array}{l}0.084 \\
(0.052)\end{array}$ & $\begin{array}{l}0.009 \\
(0.077)\end{array}$ & $\begin{array}{l}-0.129 \\
(0.096)\end{array}$ \\
\hline Lagged marriage rate & $\begin{array}{l}-0.380 \\
(0.808)\end{array}$ & $\begin{array}{l}1.257^{*} \\
(0.714)\end{array}$ & $\begin{array}{l}4.284 * * * \\
(0.943)\end{array}$ \\
\hline Lagged divorce rate & $\begin{array}{l}14.637 * * * \\
(2.857)\end{array}$ & $\begin{array}{l}9.609 * * * \\
(2.731)\end{array}$ & $\begin{array}{l}4.767 \\
(3.338)\end{array}$ \\
\hline Total fertility rate 25 years ago & $\begin{array}{l}-0.279 * * * \\
(0.053)\end{array}$ & & \\
\hline Total fertility rate 30 years ago & & $\begin{array}{l}-0.069 \\
(0.050)\end{array}$ & \\
\hline Total fertility rate 35 years ago & & & $\begin{array}{l}-0.651 * * * \\
(0.077)\end{array}$ \\
\hline $\begin{array}{l}\text { Expenditure old age benefits } \\
\text { (percent GDP) }\end{array}$ & $\begin{array}{l}0.017 * \\
(0.009)\end{array}$ & $\begin{array}{l}-0.041 * * * \\
(0.013)\end{array}$ & $\begin{array}{l}0.003 \\
(0.018)\end{array}$ \\
\hline Constant & $\begin{array}{l}3.490 \\
(4.923)\end{array}$ & $\begin{array}{l}-8.502 \\
(7.561)\end{array}$ & $\begin{array}{l}-14.772 \\
(9.309)\end{array}$ \\
\hline $\begin{array}{l}\text { Observations } \\
\text { Number of countries } \\
\text { Wald test: Prob }>\text { chi2 }\end{array}$ & $\begin{array}{l}246 \\
23 \\
0.0000\end{array}$ & $\begin{array}{l}246 \\
23 \\
0.0000\end{array}$ & $\begin{array}{l}234 \\
22 \\
0.0000\end{array}$ \\
\hline
\end{tabular}

Standard errors in parentheses

* significant at 10\%; ** significant at 5\%; *** significant at $1 \%$

The regressions are estimated using FGLS. Each regression includes country dummies. 
Table A 8: Educational attainment level in 2008

\begin{tabular}{|c|c|c|c|c|c|c|c|c|c|}
\hline Country & $\begin{array}{l}\text { Education } \\
\text { attainment level }\end{array}$ & $25-29$ & 30-34 & $35-39$ & $40-44$ & $45-49$ & $50-54$ & $55-59$ & 60-64 \\
\hline \multirow[t]{3}{*}{ Austria } & $\mathrm{P} / \mathrm{LS}$ & 0.127 & 0.160 & 0.179 & 0.205 & 0.245 & 0.327 & 0.367 & 0.381 \\
\hline & US & 0.717 & 0.625 & 0.627 & 0.620 & 0.595 & 0.541 & 0.530 & 0.464 \\
\hline & $\mathrm{T}$ & 0.186 & 0.226 & 0.184 & 0.152 & 0.145 & 0.131 & 0.113 & 0.088 \\
\hline \multirow[t]{3}{*}{ Belgium } & $\mathrm{P} / \mathrm{LS}$ & 0.153 & 0.144 & 0.199 & 0.242 & 0.307 & 0.416 & 0.482 & 0.573 \\
\hline & US & 0.399 & 0.377 & 0.411 & 0.411 & 0.376 & 0.340 & 0.305 & 0.272 \\
\hline & $\mathrm{T}$ & 0.517 & 0.492 & 0.422 & 0.361 & 0.321 & 0.255 & 0.209 & 0.196 \\
\hline \multirow[t]{3}{*}{ Cyprus } & $\mathrm{P} / \mathrm{LS}$ & 0.111 & 0.112 & 0.163 & 0.215 & 0.266 & 0.317 & 0.480 & 0.545 \\
\hline & US & 0.323 & 0.320 & 0.376 & 0.400 & 0.374 & 0.287 & 0.297 & 0.219 \\
\hline & $\mathrm{T}$ & 0.562 & 0.487 & 0.347 & 0.260 & 0.244 & 0.260 & 0.167 & 0.116 \\
\hline \multirow{3}{*}{$\begin{array}{l}\text { Czech } \\
\text { Republic }\end{array}$} & $\mathrm{P} / \mathrm{LS}$ & 0.058 & 0.070 & 0.056 & 0.095 & 0.111 & 0.187 & 0.214 & 0.216 \\
\hline & US & 0.721 & 0.815 & 0.794 & 0.802 & 0.711 & 0.727 & 0.702 & 0.722 \\
\hline & $\mathrm{T}$ & 0.249 & 0.168 & 0.125 & 0.155 & 0.137 & 0.125 & 0.075 & 0.081 \\
\hline \multirow[t]{3}{*}{ Denmark } & $\mathrm{P} / \mathrm{LS}$ & 0.132 & 0.120 & 0.136 & 0.193 & 0.245 & 0.320 & 0.300 & 0.412 \\
\hline & US & 0.401 & 0.376 & 0.395 & 0.442 & 0.413 & 0.307 & 0.364 & 0.371 \\
\hline & $\mathrm{T}$ & 0.459 & 0.488 & 0.404 & 0.383 & 0.323 & 0.371 & 0.288 & 0.214 \\
\hline \multirow[t]{3}{*}{ Finland } & $\mathrm{P} / \mathrm{LS}$ & 0.081 & 0.073 & 0.085 & 0.100 & 0.105 & 0.186 & 0.269 & 0.382 \\
\hline & US & 0.511 & 0.377 & 0.368 & 0.411 & 0.448 & 0.431 & 0.400 & 0.350 \\
\hline & $\mathrm{T}$ & 0.392 & 0.588 & 0.519 & 0.516 & 0.441 & 0.394 & 0.301 & 0.282 \\
\hline \multirow[t]{3}{*}{ France } & $\mathrm{P} / \mathrm{LS}$ & 0.164 & 0.151 & 0.211 & 0.266 & 0.344 & 0.399 & 0.459 & 0.502 \\
\hline & US & 0.395 & 0.378 & 0.418 & 0.455 & 0.425 & 0.383 & 0.348 & 0.310 \\
\hline & $\mathrm{T}$ & 0.459 & 0.439 & 0.380 & 0.286 & 0.229 & 0.201 & 0.173 & 0.155 \\
\hline \multirow{3}{*}{ Germany } & $\mathrm{P} / \mathrm{LS}$ & 0.146 & 0.155 & 0.149 & 0.146 & 0.161 & 0.171 & 0.237 & 0.256 \\
\hline & US & 0.656 & 0.573 & 0.602 & 0.627 & 0.591 & 0.583 & 0.646 & 0.558 \\
\hline & $\mathrm{T}$ & 0.235 & 0.270 & 0.239 & 0.226 & 0.210 & 0.210 & 0.199 & 0.151 \\
\hline \multirow[t]{3}{*}{ Greece } & $\mathrm{P} / \mathrm{LS}$ & 0.167 & 0.208 & 0.237 & 0.312 & 0.380 & 0.487 & 0.533 & 0.734 \\
\hline & US & 0.452 & 0.498 & 0.443 & 0.431 & 0.401 & 0.341 & 0.256 & 0.237 \\
\hline & $\mathrm{T}$ & 0.341 & 0.273 & 0.248 & 0.274 & 0.187 & 0.163 & 0.122 & 0.089 \\
\hline \multirow[t]{3}{*}{ Hungary } & $\mathrm{P} / \mathrm{LS}$ & 0.127 & 0.147 & 0.172 & 0.191 & 0.232 & 0.303 & 0.303 & 0.408 \\
\hline & US & 0.559 & 0.571 & 0.599 & 0.545 & 0.572 & 0.580 & 0.516 & 0.429 \\
\hline & $\mathrm{T}$ & 0.303 & 0.256 & 0.210 & 0.211 & 0.210 & 0.180 & 0.150 & 0.132 \\
\hline \multirow[t]{3}{*}{ Ireland } & $\mathrm{P} / \mathrm{LS}$ & 0.113 & 0.133 & 0.187 & 0.240 & 0.293 & 0.384 & 0.486 & 0.552 \\
\hline & US & 0.397 & 0.330 & 0.380 & 0.398 & 0.390 & 0.348 & 0.300 & 0.268 \\
\hline & $\mathrm{T}$ & 0.573 & 0.487 & 0.425 & 0.353 & 0.289 & 0.248 & 0.184 & 0.152 \\
\hline \multirow[t]{3}{*}{ Italy } & $\mathrm{P} / \mathrm{LS}$ & 0.257 & 0.305 & 0.363 & 0.439 & 0.466 & 0.542 & 0.627 & 0.709 \\
\hline & US & 0.534 & 0.502 & 0.437 & 0.426 & 0.403 & 0.349 & 0.259 & 0.174 \\
\hline & $\mathrm{T}$ & 0.271 & 0.248 & 0.193 & 0.146 & 0.115 & 0.120 & 0.106 & 0.070 \\
\hline \multirow[t]{3}{*}{ Latvia } & $\mathrm{P} / \mathrm{LS}$ & 0.150 & 0.131 & 0.065 & 0.060 & 0.049 & 0.067 & 0.167 & 0.223 \\
\hline & US & 0.457 & 0.511 & 0.623 & 0.605 & 0.659 & 0.618 & 0.608 & 0.513 \\
\hline & $\mathrm{T}$ & 0.380 & 0.345 & 0.329 & 0.322 & 0.314 & 0.290 & 0.257 & 0.198 \\
\hline \multirow[t]{3}{*}{ Luxembourg } & $\mathrm{P} / \mathrm{LS}$ & 0.193 & 0.212 & 0.314 & 0.339 & 0.391 & 0.461 & 0.487 & 0.548 \\
\hline & US & 0.427 & 0.365 & 0.408 & 0.408 & 0.413 & 0.397 & 0.310 & 0.301 \\
\hline & $\mathrm{T}$ & 0.460 & 0.430 & 0.293 & 0.234 & 0.196 & 0.145 & 0.162 & 0.106 \\
\hline \multirow[t]{3}{*}{ Netherlands } & $\mathrm{P} / \mathrm{LS}$ & 0.149 & 0.159 & 0.210 & 0.226 & 0.286 & 0.333 & 0.418 & 0.515 \\
\hline & US & 0.428 & 0.401 & 0.465 & 0.464 & 0.431 & 0.383 & 0.325 & 0.308 \\
\hline & $\mathrm{T}$ & 0.438 & 0.402 & 0.336 & 0.281 & 0.269 & 0.274 & 0.216 & 0.182 \\
\hline
\end{tabular}




\begin{tabular}{|c|c|c|c|c|c|c|c|c|c|}
\hline \multirow[t]{3}{*}{ Poland } & $\mathrm{P} / \mathrm{LS}$ & 0.047 & 0.075 & 0.082 & 0.092 & 0.095 & 0.160 & 0.221 & 0.321 \\
\hline & US & 0.500 & 0.566 & 0.655 & 0.716 & 0.723 & 0.674 & 0.654 & 0.530 \\
\hline & $\mathrm{T}$ & 0.397 & 0.345 & 0.250 & 0.189 & 0.153 & 0.141 & 0.116 & 0.110 \\
\hline \multirow[t]{3}{*}{ Portugal } & $\mathrm{P} / \mathrm{LS}$ & 0.393 & 0.530 & 0.611 & 0.740 & 0.781 & 0.799 & 0.873 & 0.899 \\
\hline & US & 0.253 & 0.221 & 0.171 & 0.115 & 0.114 & 0.080 & 0.063 & 0.042 \\
\hline & $\mathrm{T}$ & 0.325 & 0.269 & 0.194 & 0.152 & 0.115 & 0.104 & 0.085 & 0.075 \\
\hline \multirow[t]{3}{*}{ Romania } & $\mathrm{P} / \mathrm{LS}$ & 0.239 & 0.212 & 0.164 & 0.150 & 0.240 & 0.347 & 0.491 & 0.613 \\
\hline & US & 0.542 & 0.594 & 0.747 & 0.678 & 0.718 & 0.559 & 0.454 & 0.277 \\
\hline & $\mathrm{T}$ & 0.245 & 0.166 & 0.121 & 0.102 & 0.103 & 0.100 & 0.076 & 0.063 \\
\hline \multirow[t]{3}{*}{ Slovakia } & $\mathrm{P} / \mathrm{LS}$ & 0.050 & 0.064 & 0.057 & 0.095 & 0.102 & 0.198 & 0.227 & 0.272 \\
\hline & US & 0.712 & 0.741 & 0.739 & 0.792 & 0.754 & 0.676 & 0.651 & 0.589 \\
\hline & $\mathrm{T}$ & 0.248 & 0.172 & 0.131 & 0.150 & 0.136 & 0.134 & 0.097 & 0.082 \\
\hline \multirow[t]{3}{*}{ Slovenia } & $\mathrm{P} / \mathrm{LS}$ & 0.039 & 0.076 & 0.135 & 0.156 & 0.228 & 0.287 & 0.356 & 0.354 \\
\hline & US & 0.584 & 0.516 & 0.533 & 0.594 & 0.544 & 0.512 & 0.498 & 0.477 \\
\hline & $\mathrm{T}$ & 0.391 & 0.369 & 0.352 & 0.224 & 0.261 & 0.186 & 0.159 & 0.149 \\
\hline \multirow[t]{3}{*}{ Spain } & $\mathrm{P} / \mathrm{LS}$ & 0.320 & 0.318 & 0.387 & 0.451 & 0.534 & 0.621 & 0.716 & 0.820 \\
\hline & US & 0.290 & 0.255 & 0.243 & 0.249 & 0.227 & 0.193 & 0.148 & 0.106 \\
\hline & $\mathrm{T}$ & 0.451 & 0.464 & 0.380 & 0.316 & 0.250 & 0.195 & 0.141 & 0.097 \\
\hline \multirow[t]{3}{*}{ Sweden } & $\mathrm{P} / \mathrm{LS}$ & 0.086 & 0.073 & 0.078 & 0.098 & 0.124 & 0.150 & 0.174 & 0.272 \\
\hline & US & 0.472 & 0.448 & 0.490 & 0.580 & 0.511 & 0.520 & 0.481 & 0.480 \\
\hline & $\mathrm{T}$ & 0.459 & 0.474 & 0.404 & 0.355 & 0.337 & 0.339 & 0.327 & 0.269 \\
\hline \multirow{3}{*}{$\begin{array}{l}\text { United } \\
\text { Kingdom }\end{array}$} & $\mathrm{P} / \mathrm{LS}$ & 0.187 & 0.176 & 0.254 & 0.280 & 0.303 & 0.341 & 0.381 & \\
\hline & US & 0.448 & 0.399 & 0.394 & 0.385 & 0.382 & 0.350 & 0.328 & \\
\hline & $\mathrm{T}$ & 0.415 & 0.400 & 0.354 & 0.324 & 0.296 & 0.309 & 0.258 & \\
\hline
\end{tabular}

$\mathrm{P} / \mathrm{LS}=$ Primary/lower secondary; US = Upper secondary; $\mathrm{T}=$ Tertiary 


\section{Annex B}

\section{$\underline{\text { Partial derivative of participation rate with respect to tertiary education }}$}

The logistic regression model is given by:

(1) $\log \left(\frac{F L P_{i}}{1-F L P_{i}}\right)=\alpha_{i}+\beta_{i} * \operatorname{Ter}_{i}+\ldots+\varepsilon_{i}$

where FLP is the female labor force participation rate of age-group $i$ and tertiary educational attainment rate for age-group $i$.

Solving for $F L P_{i}$ yields the equivalent formulation:

(2) FLP $_{i}=\frac{e^{\alpha_{i}+\beta_{i} * \operatorname{Ter}+\ldots+\varepsilon_{i}}}{1+e^{\alpha_{i}+\beta_{i} * \operatorname{Ter}_{i}+\ldots+\varepsilon_{i}}}$

The first derivative of the female participation rate with respect to tertiary education gives:

(3) $\frac{\partial \text { FLP }_{i}}{\partial \operatorname{Ter}_{i}}=\frac{\beta * e^{\alpha_{i}+\beta * \operatorname{Ter}_{i}+\ldots+\varepsilon_{i}}}{\left(1+e^{\alpha_{i}+\beta * \operatorname{Ter}_{i}+\ldots+\varepsilon_{i}}\right)^{2}}$ 